\title{
DIREITO INDUSTRIAL
}

\section{$\sim \sim \sim \sim \sim \sim m$ \\ Marcas de fabrica e de commercio}

\author{
Stummario: \\ I.-Noção e definição de marca iudustrial. \\ II.-Utilidade e importancia das marcas. \\ III.-A marca é um direito,-direito de \\ propriedade industrial. \\ IV.-Objecto das marcas. \\ V.-Seus caracteres: a) essencial, e b) \\ accidentaes. \\ VI. -O que póde constituir marca. \\ VII.-O que não póde, e em que condi- \\ ções, constituir marca. \\ VIII.-Distincção entre marca verbal, de- \\ nominação e nome commercial ou industrial. \\ IX.-Divisão e classificação das marcas.
}

\section{l.-Noção e definięão de maréa industrial}

1.-Nomina, escreve STraccha, inventa sunt ut homines agnoscentur, et signa ut res indicentur (I). E

(I) Straccha, De Mercatura, p. II n. 7I. A proposição do eminente commercialista teria sido mais rigorosamente scientifica se, em vez de «homines», elle houvesse dicto "persona», expressão esta comprehensiva de todos os titulares ou sujeitos de direito; assim como «res», em accepção ampla é-todo objecto de direito. 
de facto, assim como os appellidos individuaes e patronimicos, nomes, firmas e razões sociaes servem para designar na scena da vida as pessoas naturaes e as juridicas, e discriminal-as umas das outras, assinn tambem servem as marcas de industria e de commercio para, na economia social, individualisar os productos e mercadorias, neste sentido de lhes assignalar a origem.

2.-A marca de fabrica ou de industria tem por fim principal-indicar a proveniencia originaria, primitiva do producto, a saber -o seu fabricante ou productor, o estabelecimento onde foi produzido, ou a localidade ou região da sua proveniencia. O fim da marca de commercio é assignalar a procedencia commercial da mercadoria (2), isto é-qual o commerciante que a vendeo.

3.-A legislação patria, como se vê de varios textos de leis e decretos regulamentares sobre essa especialidade juridica, emprega indistinctamente as expressões-marcas de fabrica e de commercio, marcas de industria e de commercio, e algumas vezes, em accepção generica, simplesmente - marcas industriaes. Assim tambem, o legislador brazileiro serve-se da locução

(2) Embora, na technologia economica, producto seja synonimo de mercadoria, por isso que produzir, em Economia Politica, é-expôr á venda; ha todavia, na linguagem commum, a seguinte distincção entre os dois vocabulos: producto é cousa engendrada ou fabricada pelo trabalho ou pela industria, á medida que mercadoria é o producto posto no giro commercial.

Sobre a mesma distincção diz elegantemente PıPIA, Nozioni di Diritto Industriale, n. 239 :

«Nel diritto adierno CosA é qualunque entità materiale od immateriale, suscettibile di obbiettività giuridica: le cose sono qualificate BENI, avuto riguardo all'utilità economica che ne deriva.

La cosa che in sè non è MERCE. è chiamata tale quando viene considerada come oggetto del commercio: nna cosa che è ancora nelle mani del produttore $\dot{e}$ PRODOTTO MANUFATTO; diventa MERCE solo quando viene ad essere oggetto del suo commercio; cessa di essere MERCE quando esce dal commercio e trovasi ad esempio nel patrimonio del consumatore.» 
nome commercial, comprehendendo nella egualmente o nome industrial (3).

4.-A lei italiana de i 868 adopta as expressões - marca e signaes distinctivos de fabrica (4), dando assim uma intelligencia restricta á noção de marca.

Este systema merece de Morse Amar calorosos applausos, porque, explica este escriptor: « . . coll' adottata elocuzione vengono ad essere eliminate molte difficoltà di cui fornisce esempii la giurisprudenza di quei paezi, nei quali la legge procedette per mezzo di enumerazioni o dell'espressione sintetica de MARCHIO» (5).

Não vamos neste ponto com o illustre jurisconsulto italiano. Affigura-se-nos, ao contrario, defeituosa a formula que elle applaude. $\mathrm{Na}$ verdade, ou ella pecca por erronea ou é redundante. E' um erro excluir-se da noção de marca a idéa de signal. Se, porém, essa idéa não está eliminada, na mente do legislador italiano, então a sua formula envolve um pleonasmo. N'outros termos: ou as marcas comprehendem todos os signaes distinctivos, e neste caso era excusada a addição destas palavras; ou pretende o legislador italiano que marcas e signaes distinctivos são cousas diversas: e tal proposição é temeraria, como havemos de ver.

Devemos, entretanto, declarar desde já que, para nós, marca é genero, e signal distınctivo-especie.

(3) L. n. 2682 de 23 de Outubro de 1875 , arts. $1 .^{\circ}, 3 .^{\circ}, 6 .^{\circ}, \S$ г.$^{\circ}$, I0. ${ }^{\circ}$, Lei n. 3346 , de I4 de Outubro de I887, titulo, e arts. $2 .^{\circ}$, I $4 . .^{\circ}$, n. I..$^{\circ}$, $4 .^{\circ}$ e $7 .^{\circ}$; art. $14 \S 2 .^{\circ}$, art. 15 , ns. $1^{\circ}$ e $30^{\circ}$ e art. 27 ; Decr. n. 9828 , de $3 \mathrm{I}$ de Dezembro de 1888 , titulo, arts. $1 .^{\circ}, 7 .^{\circ}, 9^{\circ}, 22$ e n. $2 .^{\circ}$, arts. 27,36 , ns. $10^{\circ}$ e $4 .^{\circ} ; 37$, n. $3 .^{\circ}$; L. n. 5.424 de 24 de Setembro de 1904 , art. $20^{\circ}$ I 3 , ns. 5,6 e 9 ; I4, ns. I e 3 ; Codigo Penal, arts. 353 princ. e $\$ \S 3$ e 6 ; art. 355 ; Decr. n. 3.084 de 5 de Novembro de 1898 , arts. 57 lettra j P. I; e arts. 89 e 9 I P. IV.

(4) Lei do Reino de Italia, de 30 de Agosto de 1868, arts. I. ${ }^{\circ}, 3^{\circ}$, $4 .^{\circ}, 6 .^{\circ}, 7 .^{\circ}, 90^{\circ}$ e $12 .^{\circ}, i b i:$ « . . i marchi ed $i$ signi distinctivi di fabrica."

(5) Molse Amar, Dei Nomi, dei Marchi e degli altri Signi, n. 26. 
5.-Que se entende por marca de fabrica e de commercio? Poullegr, acatado como eximio mestre por quantos se dedicam ao estudo destes assumptos, dá-nos a seguinte definição: «La marque est un moyen matériel de garantir l'origine ou simplement la provenance de la marchandise aux tiers qui l'achètent en quelque lieu et en quelque main qu'elle se trouve» (6).

Reproduzindo esta definição, Amar a mutila. Supprime nella as expressões «... ou simplement la provenance»; suppressão tanto mais grave quanto-são exactamente essas palavras que respondem á critica por elle formulada (7).

Effectivamente, repelle este escriptor a definição de Pouillet, porque, em seu conceito, a marca não tem por fim assignalar a origem da mercadoria: assim, por exemplo, as marcas de commercio. Ora, estas, como vimos, indicam a origem mercantil, a proveniencia, a saber-o intermediario entre o productor e o consumidor, ou algum dos intermediarios, quando são muitas as escalas da mediação commercial.

6.-A definição proposta por Amar é a seguinte: «I marchi o signi distintivi di fabrica sono-quei mezzi materiali coi quali taluno può distinguere $i$ prodotti della sua industria, le mercanzie del suo commercio e gli animali di una razza a lui appartenente» (8).

Não vemos porque, seguindo o methodo synthetico (e nem outro póde ser observado n'uma definição) accrescenta o autor este ultimo objecto: "gli animali, etc.»! Pois, não estava já comprehendida esta

(6) Pouillet, Traité des Marques de Fabrique, n. 4 .

(7) AMAR, obr. cit., n. 28.

(8) AMAR, obr. cit., n. 27. Agora emprega elle a preposição disjunctiva $o$, em vez da copulativa $e$ do texto legal. Se, como parece na difinição, marca e szgnaes distinctivos são synonymos, então não é correcta a formula do texto que AMAR acceitou. Ou bem uma ou bem outra opinião! 
especie no genero «i prodotti della sua industria»? Terá tido escrupulo o insigne jurisconsulto em considerar como productos da industria pecuaria os animaes de uma raça espécial pertencente álgum criador?!

Sem esta superflua addição, parece-nos muito acceitavel a definição de Amar. Embora insista o auctor em extremal-a da de Pouillet, salientando que a marca tem por fim assegurar vantagens ao industrial e ao commerciante, e não ao consumidor, e que, portanto, deve ser definida sob esse ponto de vista; todavia, encarado o assumpto não em sua superficie, mas no fundo, as definições se approximam uma da outra. Pois assignalar ao consumidor, pela marca, a origem do producto ou a proveniencia da mercadoria - , ao mesmo tempo, consultar o interesse do habil productor ou do honrado vendedor, que as tenham assignalado com as suas marcas.

7.-Dufourmantelle propõe a seguinte definição de marca: «...tout signe servant à distinguer les produits d'une fabrique ou les objets d'un commerce.» (9)

Não temos como feliz nesta definição a formula «tout signe.» $\mathrm{Ha}$ marcas industriaes e commerciaes não consistentes, propriamente, em algum signal: As marcas meramente verbaes, por exemplo, são, muitas vezes, independentes de qualquer forma configurativa. A expressão signe applica-se a esta especie? IE' licito duvidar-se. $O$ vocabulo francez signe tem significação mais restricta que o seu correspondente-sigr:al, no nosso vernaculo; pois signe é sempre tomado em accepção material, accessivel á vista, á medida que signal traduz, além dessa significação, a do seu homonymo francez - signal. (9) Dufourmantelle, Code manuel de Droit Industriel, v. III,
pag. 58. (9) Dufourmantelle, Code manuel de Droit Industriel, v. III,
pag. 58. 
8.-Muito approximada dessa é a definição adoptada por LUCIEN BRUN: "Tout signe quelconque qur individualise les produits d'un fabricant ou les marchandises d'un commerçant.» (10).

Embora affirmando que o legislador francez não pretendeo no art. I. ${ }^{\circ}$ da Lei de 1857 fazer uma enumeração taxativa das combinaç̃os que podem constituir marcas de industria e de commercio, pretende esse auctor deduzir daquella emuneração meramente enunciativa a sua definição, que acima fica. Entretanto para nós, as expressões «tout szgne quelconque» são limitativas; e, pois, restringem inconvenientemente a amplitude do texto legal.

Para a confirmação deste conceito não é necessario mais que a reproducção do mencionado art. $\mathrm{I}^{\circ}$ da lei de 23 de Junho de i 857.- Eil-a: «.... Sont considerés comme marques de fabrique ou de commerce, les noms sous forme distinctive, les dénominations, emblêmes, empreintes, timbres, cachets, vignettes, reliefs, lettres, chiffres, enveloppes et tous les autres signes servant à distinguer les produits d'une fabrique ou les objets d'un commerce.》

9.-E' a seguinte a definição dada por BEDARRI$\mathrm{DE}$ : «La marque de fabrique ou de commerce est tout signe, emblême ou dessin par lequal un fabricant, manufacturier ou commerçant désigne les produits qu'il crée ou q'uil exploite.» (I I)

Tem, como se vê, esta definição os mesmos defeitos notados nas anteriores. Para que, portanto, reproduzirmos a critica já enunciada?

pag. 2.

(I0) Lucien Brun, Les Marques de fabrique et de commerce, 2." ed.,

(I I) BeDarride, Commentaire des lois sur les Brevéts d'Invention etc., tom. III, n. 816 . 
10. - E' tempo, porém, de tirarmos a conclusão do que vimos expondo:

Acceitamos, ligeiramente modificada, a definição de Pouiltet, e assim definimos as marcas de industria e de commercio: «o meio material de assignalar aos compradores a origem dos productos, ou a procedencia das mercadorias.»

A nossa lei patria de 14 de Outubro de 1887 textualmente reproduzida nesta parte pela de 24 de Setembro de i 904, dispõe em seu art. 2. ${ }^{\circ}$ o seguinte: "As marcas de industria e de commercio podem consistir em tudo o que esta lei não prohiba e faça differençar os objectos de outros identicos ou semelhantes de proveniencia diversa.»

Embora pelo methodo de exclusão, eis ahi uma excellente noção de marca de fabrica! (12)

Adiante analysaremos a disposição deste texto.

(12) São muito judiciosas as considerações adduzidas sobre este ponto pelo Conde MalllaRd DE MARAfy, em seu importante livro, com que fomos mimoseados pelo eminente autor, o Grand Dictionnaire international de la Propriété Industrialle, verb MARQUE, ibi n. 3: "DEFINITION DE LA MARQUE: - Les meilleurs esprits sont très divises sur le point de savoir si la marque doit être définie dans la loi qui doit la réglementer. Nous sommes de ceux qui pensent qu'il n'y a pas lieu de s'arrêter à la difficulté toujours opposée OMNIS DEFINI'IO PERICULOSA. Nous estimons même que la meilleure définition ne dispense pas d'une énumération, à titre enonciatif, des princèpaux signes pouvant constituer une marque. Les adversaires de la définition allèguent qu'elle est inutile, tout commerfant sachant parfaitement ce qu'est une marque de fabrique ou de commerce. Ils ajoutent que la définition offre le grave danger d'être limitative.

4.-Des jurisconsultos moins timorés considèrent qu'une défnution est indispensable, mais à la condition de la faire aussi large que possible, et de ne pas risquer de la restreindre par une énumeration méme énonciative. Tels sont les arguments qui ont été présentés lors de la diseussion de la loi brésilienne qui a eu, dans les deux pays, un très vif éclat.»

Tivemos empenho em transcrever até o fim este trecho, por ser muito honroso para o nosso paiz, especialmente para o antigo Senado brazileiro, onde se deram os luminosos debates aos quaes se refere o autor. 


\section{II.-Itilidade e importancia das mareas}

11.-As marcas, como temos visto, interessam ora principalmente á industria, ora principalmente ao commercio.

Dessa differença resulta a classificação dellas em - marcas industriaes e marcas commerciaes.

As primeiras são tambem denominadas-marcas de fabrica, expressão mais restricta e que, por isso mesmo, deve ser preterida; pois nem todos os productos da industria, susceptiveis de serem marcados, são productos de fabrica. Esta designação, por acanhada, excluiria, além de outras, as producções da industria agricola, da pecuaria e da extractiva.

12. - Dupla é a vantagem da marca industrial: assignala, primeiramente, aos consumidores a origem do producto industrial; e, dadas as salutares precauçơes com que a lei positiva sóe acautelar, em todas as nações cultas, a adopção e o registro das marcas, licito é acreditar-se que aquella indicação de procedencia vem revestida do caracter de authenticidade.

Assim, não é illaqueada a boa fé do publico. Quem procure, pelo conhecimento que tenha da competencia do productor ou de outras condições especiaes da producção, certas e determinadas mercadorias, terá a facilidade de obtel-as genuinas, uma vez que assignaladas por marca designativa da sua origem.

13.-Por outro lado, a marca tambem garante os direitos e interesses do industrial.

Se este se obstina, pela applicação da sua intelligente actividade, pela persistencia no trabalho e pelo emprego de capitaes ás vezes avultados, por alcançar o aperfeiçoamento da sua produç̧ão industrial; e se, 
por fim, á custa de taes ìs sacrificios, attinge áquelle desideratum: não terá mais, para assegurar o fructo de tantos esforços, do que adoptar para os seus productos qualquer marca que os caracterise, discriminando-os dos productos similares, de procedencia diversa.

Dahi por diante, estimulado moralmente, pois que a marca adoptada será como que um cunho da sua personalidade; estimulado por interesses economicos, porque a marca industrial constitúe uma propriedade cujo valor cresce na razão directa da excellencia dos productos a que ella se applica: o industrial envidará todos os meios para manter, ou augmentar cada vez mais, os creditos adquiridos pela sua industria.

14.- Menos uteis não são as marcas para os commerciantes do que o são, como acabamos de ver, para os industriaes e para todos os productores, em geral.

Se a estes interessa que não sejam confundidos os seus productos com os dos seus concurrentes, tambem interesse egual ha de ter o commerciante intelligente e acreditado. E' da conveniencia delle que conheça o publico as mercadorias vendidas em sua casa commercial, e não as confunda com as dos seus concurrentes, menos escrupulosos talvez. Dá-se frequentemente, com effeito, a falsificação de productos por intermediarios deshonestos. E', por isso, ponto relevante para o commerciante honrado que compra productos genuinos e, sem alteral-os, os revende; que os compra dos melhores productores, e destes a sua melhor producção: que sejam assignaladas para os consumidores as mercadorias oriundas do seu estabelecimento mercantil. As marcas de commercio são o meio legal e efficaz de que elle dispóe para tal fir.. 
15. - Não defluem de meras inducções do nosso espirito essas proposições que ahi ficam. A diaria experiencia dos factos egualmente as proclama.

Quem, com effeito, não tem observado a predilecção com que a grande massa dos consumidores de um artigo industrial, de um genero agricola, se empenha na procura das marcas mais conhecidas e acreditadas no mercado, daquellas recommendadas pela notoria superioridade dos productos que dellas se revestem?

16. - E quanto ao commercio, não nos diz, tambem, constante observação que numerosa clientela se encaminha para as casas mais acreditadas pela seriedade das suas normas commerciaes? $\dot{E}^{\prime}$ frequente esse facto, e tanto mais expressivo quanto, muitas vezes, não é a modicidade dos preços a sua causa determinadora, mas, exactamente, o fito, por parte dos consumidores, de obter mercadorias de boa qualidade, em estado perfeito e de authentica procedencia.

Quem desconhece em Paris o valor accrescido a um producto comestivel, se elle está revestido da marca commercial de Potrs? Quem não adquire com maior confiança, em S. Paulo, o cognac Jules Robin, se as respectivas garrafas trazem no sub-rotulo a marca commercial dos Snrs. Trommel \& Comp., importadores desse producto?

17.-Estudada a importancia das marcas sob o ponto de vista do apreço que lhes dão os respectivos donos, a saber os industriaes e commerciantes que as tenham adoptado, não menos significativos são os factos que a cada momento se produzem.

Que denunciam, na verdade, esse constante esforço e esse cuidado incessante e solicito com que cada qual defende o uso exclusivo de suas marcas e reclama pela efficacia dessa defeza a poderosa inter- 
venção do poder publico? Que revela esse facto, a nạoo ser a affirmação da importancia das marcas de industria e de commercio?

18. - E não é sobmente á invocação dos meios repressivos que póde recorrer o dono da marca violada. $O$ direito lhe faculta paralellamente o amparo de acção civil para a indemnisação de damnos causados com a violação das suas marcas. Ora, essa instituição juridica vem evidentemente confirmar o alcance economico da marca, assim como a penalidade revela a sua importancia social.

Duplamente attentatoria á propriedade industrial, a infracção da marca constitue ao mesmo tempo duas figuras juridicas. E' um roubo ou um furto, em face de direito penal, uma depredação em direito civil. O primeiro facto faz incidir o infractor n'uma penalidade, o segundo obriga-o a uma indemnisação (I 3).

\section{III. - A marea é um direito, direito de propriedade.}

19. - São as marcas de fabrica e de commercio ou (para empregarmos uma expressão generica á qual já demos preferencia) as marcas industriaes um meio destinado a assignalar a procedencia dos productos ou das mercadorias.

Indagam, por isso, os jurisconsultos se ellas são facultativas ou se obrigatorias; n'outros termos:- se as

(13) Lei n. 1236, de 24 de Setembro de 1904, arts. I3 e 18.-DuCREUx, Dessins et Modèles de Fabrique, n. I17: "La contrefaçon est à la proprieté intellectuelle ce que la soustraction ou la détention est à la propriété mobilierè; le contrefacteur est en quelque sorte soumis à une véritable action en rêvendication, car il s'est servi du bien d'autrui." Noutro lugar da mesma obra, (n. 8I) o autor se exprime ainda com maior energia sobre o attentado á propriedade industrial. "... Somme toute, la contrefacon est un vol, c'est prendre à autrui le fruit de son travail; il $y$ a les mêmes raisons pour réprimer pénalement cet acte que pour frapper celui qui s'attaque à la propriété matérielle d'autrui.» 
marcas constituem para a industria e o commercio um direito ou uma obrigação.

Sobre este ponto, chegaram a accorde solução a doutrina e a jurisprudencia, o direito civil e o internacional privado, firmando como regra geral-que as marcas são facultativas. A adopção e o emprego dellas dependem da exclusiva vontade do industrial ou do commerciante (I4).

20. - Soffre, todavia, este principio geral excepções, ainda que mui raras. Systema diverso seria incompativel com os principios fundamentaes do direito publico moderno, especialmente com o da liberdade da industria.

Assim, quando ha interesse publico em se tornar conhecida a proveniencia de certos productos, impõe a lei como obrigatoria a apposição nelles de marcas designativas da sua origem.

Comprehende-se que tal providencia póde ter como objectivo tanto a protecção á boa fé dos compradores, como a vantagem de se apurar a responsabilidade eventual, no caso de damnos resultantes da acquisição ou do uso do producto ou da mercadoria.

Sem necessidade de nos alongarmos mais sobre tal objecto, limitar-nos-emos a lembrar que, de facto,

(I4) Ha, entretanto, alguns escriptores que propugnam com ardor o systema da obrigatoriedade das marcas. Occupa entre elles posição saliente M. Huard, que n'um, importante estudo inserto na Propriété Industrielle, assim se exprime.

«A cada qual a responsabilidade das suas obras boas ou más: eis o principio cuja applicação pedimos.

A moralisação do commercio, a independencia do fabricante eis-o rezultado a que visamos. A marca obrigatoria consagra o principio e assegura os rezultados.»

Esta opinião, porém, é anachronica, eivada de proconceitos medievaes. Refutam-n'a victoriosamente quasi todos os escriptores que se occuparam do assumpto até meados do seculo passado. Aincla em 1887, no Senado brazileiro foi o assumpto brilbantemente discutido pelos senadores CoRRÊA E AFFONSO CELSO. 
existe interesse publico em certos casos, alguns desses expressamente reconhecidos pelo direito patrio, em se assignalar a origem os productos industriaes. Mencionemos como exemplo os artefactos de ouro ou prata (I 5), os productos therapeuticos, ( I6) trabalhos typographicos, lithographicos, de gravura e outros ana$\log$ os (I 7 ).

As marcas e indicações de procedencia perdem em taes hypotheses, o seu caracter normal e se revestem do de garantias sobre a composição do producto, ou de providencias preventivas para a responsabilidade pela sua autoria. $O$ interesse mercantil passa para segundo plano, ficando em primeiro interesses de ordem publica.

21. - Objectivamente consideradas, as marcas industriaes (1 8) constituem um direito, uma propriedade dos productores ou commerciantes que as tenham legitimamente adoptado para individualisarem os seus productos ou mercadorias.

Ainda que repellida com vigor por alguns jurisconsultos, essa doutrina tem, entretanto, o assentimento da generalidade dos escriptores modernos, e representa accentuada evolução no direito.

Essa propriedade, porém, -é de direito civil ou de direito natural? (I9)

(15) Reg. de 17 de Janeiro de 1735 ; Decr. de 16 de Outubro de 1820.

(16) Decr. n. 9554 de 3 de Fevereiro de 1886, arts. 55 e 60; Decr. do Estado de S. Paulo, n. 394 de 7 de Outubro de 1896 , arts. 62 e 69.

(I 7$)$ Cod. Pen. Braz., art. 384 .

(r8) Como já dissemos, na expressão marcas industriaes comprehendem-se geralmente as marcas de commercio; e com razão, porque o commercio industria é, no sentido generico deste vocabulo. Sob as denominações-propriedade industrial, marca industrial, o nosso direito inclue as relativas á agricultura e industrias pecuaria e extractiva. Essa technologia, aliás corrente na jurisprudencia patria, foi expressamente consagrada no Protocollo de encerra. mento da Convenção de Paris, de 20 de Março de 1883 , promulgada no Brazil pelo Decr. n. 9233 de 28 de Junho de 1884 ,

(I9) A. Darras, Marq. de Fabr. et de Comm. ns. I e seguintes; Th. Dunant, Marq. de Fabr. et de Comm. n. 48. 
Não se imagine que seja méramente doutrinaria tal distincção. Aliás, destituida de alcance pratico, não n'a discutiriam com tanto ardor os mais notaveis tractadistas que se tem occupado do relevante assumpto da propriedade industrial (20).

22. Se o direito sobre as marcas industriaes fosse uma creação da lei civil, elle não existiria senão a partir do momento em que o industrial ou o commerciante tivesse preenchido as condições que a lei prescreve para a protecção da marca. E assim, as marcas não registradas não teriam existencia juridica; dellas nenhum direito reverteria para o seu inventor. Se outro industrial ou commerciante as adoptasse posteriormente e as fizesse registrar, - nenhuma injuria praticaria, com tal procedimento, ao seu inventor e primeiro possuidor; e este nenhuma reclamação fundada poderia formular contra aquelle, o qual seria, juridicamente, o primeiro occupante de uma res nullius.

Taes são os legitimos e inevitaveis corollarios da doutrina que considera de direito civil a propriedade das marcas de fabrica.

23.-Desde, porém, que se affirme o principio de que essa propriedade é de direito natural, ou de direito commum, consagrada e regulada, embora, por direito civil especial, pelos principios anomalos da legislação, industrial: então, differentes deverão ser as conclusões a se deduzirem.

Posto que desamparado da protecção especial das instituições civis peculiares ás marcas de fabrica,

(20) O Congresso Internacional para a Protecção da Propriedade Industrial, reunido em Paris no anno de 1878 adoptou, entre outras, a seguinte conclusão:

«O direito dos inventores e dos autores industriaes sobre as suas obras, o dos fabricantes e dos negociantes sobre as suas marcas.- é um direito de propriedade. $>$ 
o industrial despojado por outrem da sua propriedade não registrada, teria, para se desaggravar deste attentado, a protecção do direito commum.

Este principio está expressamente consagrado na legislação patria a qual, embora exija para a garantia do uso exclusivo das marcas registro, deposito e publicidade das mesmas (2 I), não obstante, não isenta de responsabilidade pelos damnos causados aquelle que tenha feito registrar para si alheia marca não registrada pelo dono (22).

24. - Neste assumpto, desenvolvidamente discutido por eminentes jurisconsultos, opinaram pela primeira solução, entre os escriptores que temos manuseado, Poulllet (23), Bedarride (24), A. Braun (2.5), Gastão Mayer (26) e, entre nós, o Dr. Didimo DA VEIGA (27).

Sustentam a doutrina opposta, a saber--que o direito civil não creou, mas apenas reconheceu e regulamentou, a propriedade industrial, entre outros, os seguintes autores: Rendu (28), Pataille (29), Riviere e André Weis (30), Georges Bry (31), Blanc (32), Dufourmantelle (33), Edmond Aubin (34), A. Lam-

(2x) Lei n. 1236 de 24 de Setembro de 1904, art. $3 .^{\circ}$

(22) Lei n. 3346 de 14 de Outubro de 1887 , art. 23, segunda parte, não modificado pela Lei n. I 236 cit.

(23) Poulllet, Marq. de Fabr. $4 .^{{ }^{a}}$ ed. n. 77.

(24) BeDARRIDE, Breveits d'Invent. etc. n. 848 .

(25) A. Brann, Marq. de Fabr. n. Io.

(26) Gaston Mexer, De la Concurr. Deloyale etc.

(27) Didimo Veiga, Marcas de Fabr. pag. 2.

(28) RFNDU, Marq. de Fabr. n. II3.

(29) Pataille, Ann. de la Propr. Ind. tom. XXXIII.

(30) Rivière E André WeIs, Pandect. Franç., vol. Propr. litter., art. $e$ industr. ns. 52 e seguintes.

(31) GORGES BRy, Cours de Legisl. Industr., pag. 80.

(32) Blanc, De la Contref. $40^{\mathrm{a}}$ ed. pag. 765.

(33) Dufourmantelle, Man. de Droit. Ind. pag. 80.

(34) Edm. AUbIN, Du Nom Comm. Introd. 
bert (35), e, no Brazil, o Snr. Visconde de Oúro Preto (36).

25. - Esta mesma questão foi objecto de brilhantes debates no Senado Brazileiro, nas sessões legislativas de I 875 e de I 887 , quando naquella casa foram discutidos os projectos posteriormente convertidos nas leis de 23 de Outubro de 1875 e de I 4 de Outubro de 1887 .

$\mathrm{Na}$ sessão de 4 de Setembro de 1875 , dizia o eminente jurisconsulto Conselhetro Nabuco, em sustentação de emenda sua que foi approvada:

«Senhores, quem vê a disposição deste artigo «Ninguem poderá pretender a propriedade da marca sem que préviamente a tenha registrado no tribunal etc.», deve suppôr que esta lei é que confere a propriedade da marca; que a propriedade da marca provem desta lei; que sem a formalidade exigida pelo art. $20^{\circ}$ desta lei não ha propriedade de marca. Mas, senhores, esta propriedade vem do principio de direito-suum cuique: eis ahi a base da propriedade da marca.

Esta lei não deve dizer senão o que diz a lei franceza: cada um póde usar da marca que quizer, cada um tem a propriedade da sua marca, sujeitando-se, porém, simplesınente ás condições do direito commum, isto é-tendo sómente a acção de damnos e interesses que provem de um damno causado á propriedade de outro. Esta lei o que póde dizer e diz é que ninguem poderá ter a protecção que ella dá por meio de acção criminal, senão preenchendo o disposto nella» (37).

26.- Não menos memoraveis são os conceitos externados sobre o mesmo ponto de direito pelo SNR.

(35) A. Lambert, Man. de la Prop. Ind. et Comm. pag. 64.

(36) V. DE OURo Preto; Marc. Industr. e Nome Comm. pag. 28,

(37) Annaes do Senado Brazileiro, vol. V de 1875. 
Conselheiro Afronso Cerso. Dizia o preclaro parlamentar na sessão de I. $^{\circ}$ de Agosto de 1887:

«Dessas questões as principaes podem assim resumir-se: é do registro que origina-se o direito de propriedade sobre a marca?

Direi a S. ${ }^{a}$ Ex. ${ }^{a}$ (ao Snr. Senador Correia) que não é do registro que procede o direito da propriedade sobre a marca, pois que elle é apenas a constatação legal de que alguem assumio-a e reserva-a para si, a notificação official ao publico de the ser interdicto o seu uso, sob as penas da lei.

Esta é a doutrina mais corrente; proclamam-n'a todos os tratadistas, firmados em numerosos arestos da jurisprudencia estrangeira, dos quaes decorre o principio fundamental que o nobre Senador citou:-o registro ou deposito (como outras legislaçốes o denominam), é simplesmente declarativo e não attributivo da propriedade da marca; o registro não a confere, revela-a.

O Snr. Vieira da Silva:-O registro é attributivo, segundo a lei allemã; mas os publicistas mais modernos entendem que é declarativo.

O Snr. Afforso Celso. - No regimen do projecto, é declarativo e comprobativo. Não crea a propriedade, mas é só por meio delle que perante os tribunaes se póde proval-a, para obter a garantia especial da lei. Adquire-se a propriedade da marca pelos mesmos meios de direito por que se adquire qualquer outra, porém mais ordinariamente pela invenção ou occupaşão» (38)

27.-Não vemos porque se deva considerar creação arbitraria do legislador soberano a propriedade

(38) Annaes do Senado Brasileiro, Vols. II e III de 2887. 
industrial. Para nós, não se reveste essa instituição do caracter de uma concessão outhorgada, de um favor liberalisado; ella é a expressão de um direito. E em tal conjuntura, não podia a lei positiva deixar de amparal-o (39).

Tem o homem direito absoluto sobre a sua pessôa, portanto sobre a sua actividade, o seu trabaiho. Elle adquire propriedade incontestavel sobre os productos rezultantes do exercicio de sua actividade. Além dessa propriedade, que se concretisa em cada objecto produzido, e póde ser transferido a terceiros, uma outra se origina, e esta não se transfere com a comprá do producto: é a marca.

28.- A propriedade da marca é immaterial. Consiste exactamente, como temos visto, no direito de assignalar os productos ou mercadorias, de modo a se lhes conhecer a origem industrial ou commercial. Salvo algumas limitações legaes determinadas por interesse de ordem publica ou relativo atrazo na evolução do direito, tem essa propriedade todos os fundamentaes caracteristicos de um direito real. Assim, póde o seu proprietario, preenchidas as prescripções de direito, della usar, gozar e dispôr, de modo independente do des-

(39) Não são uniformes nas legislação das nações modernas a natureza e os effeitos juridicos dos registros das marcas de industria e de commercio. Assim a prioridade do registro importa a appropriação da marca, sem embargo do uso anterior da mesma por um terceiro, nos seguintes paizes:

Allemanha, Estados Unidos, Republica Argentina, Chile, Suissa, Uruguay, Venezuela e Australia.

Ao contrario a precedencia do uso é decisiva, para a appropriação da marca nos Estados seguintes:

Brazil, França, Belgica, Italia, Russia, Dinamarca, Hollanda, Suecia e Noruega, Turquia e Canadá.

Um systema mixto, informa Donzel, adoptado pela Inglaterra, o Cabo, Victoria e a Hespanha, consiste n'uma intimação feita a quem direito pelo registrante para produzir um titulo dentro de prazo legal, findo o qual sem opposição, o registro fica attributivo de propriedade. Este processo, diz o Conde MAILlARD DE MARAFY, tem a vantagem de impossibilitar qualquer sorpreza, desde que o prazo seja sufficiente. 
tino dos productos ou mercadorias que as marcas revestem.

\section{IV. - Objecto das mareas}

29. - Que productos ou mercadorias podem ser assignalados pelas marcas de industria e de commercio?

A esta interrogação os autores conceituosamente respondem que - todos. Sim, todas as cousas produzidas pela industria, na sua mais ampla accepção, ou offerecidas á venda pelo commercio: - são susceptiveis de ser marcadas de modo a se lhes poder discriminar a proveniencia, valorisando-as por esse modo.

30. - E tambem, como corollario dessa proposição: - a todo industrial ou negociante assiste a faculdade de precaver os seus interesses, adoptando marcas especiaes para todos os objectos da sua producção ou do seu negocio.

«Tout fabricant, tout négociant, diz Poutller, quelque soit son genre de commerce ou d'industrie, a le droit d'avoir sa marque» (40).

31.-Duvidou-se, attesta o mesmo escriptor, se os productos pharmaceuticos podem se revestir de marcas industriaes. Fundava.se a vacillação sobre o caracter especial desses productos. Interessando a saúde publica, devem elles permanecer no dominio commum, de modo a não serem as respectivas formulas exclusiva propriedade de alguem. Tal prerogativa lhes daria a condição de odioso monopolio, incompativel com o interesse da collectividade social.

Esta argumentação é improcedente. A marca não induz o monopolio da producção; pois aquella é dis-

(40) Pouillet, obr. cit. $\mathrm{n}^{\circ}$. 15 . 
tincta do objecto a que se applica. A qualquer outra pessoa não é vedado produzir gentros similares; mas tão sómente empregar nelles alheia marca.

32. - A' parte a propriedade das formulas pharmaceuticas, garantidas por patentes de invenção, cujo estudo comporta largo desenvolvimento, mas seria deslocado neste ponto: que incompatibilidade póde haver entre o preparo ou o cornmercio de productos chimi$\cos$, de effeito therapeutico, e o direito de os marcar os seus autores ou vendedores?

«N'y a-t-il pas, accrescenta PouIllet, parmi les pharmaciens comme chez tous les autres fabricants, des intelligences et des probités differentes? Tel, plus savant ou seulement plus hounête, saura mêler et combiner avec art les ingrédients qu'il emploie, il les choisira plus purs, au risque de les payer plus cher, il mettra plus de soin à les preparer, il imaginera d'ingénieux procédés de fabrication, il mettra en ceuvre des machines perfectionnées; n'est-il pas juste qu'il recueille le bénéfice de sa science, de son talent, de son honnêteté? Et comment le recueilleva-t-il, s'il lui est défendu de marquer ses produits et de les distinguer de ceux des autres pharmaciens??

33. - Subscrevendo a essa doutrina, Allart a confirma com a citação de uma memoravel sentença do Tribunal de Commercio de Sena, de 27 de Março de 1856 (4 I).

Diz-se neste aresto: "Si le droit de préparer des médicaments inscrits au Codex est libre pour tous, la préparation de ces médicaments peut être obtenue à l'aide de méthodes plus ou moins parfaites; là est le champ industriel où chacun peut développer son intelligence à

(4I) Henri Alart, De la Pharmacie au point de vue de la Propriété Industrielle, pag. $7 \mathrm{I}$. 
son proft. Il s'en suit le droit évident, pour celui qui a perfectionné certain produit, d'y attacher son nom, qui devient alors nne propriété commerciale, inviolable, ou de le désigner par certaines appellations que les concurrents doivent respecter pour ne pas produire une confusion qui pourvait être dommageable.»

34. - São applicaveis os mesmos principios, e com razão maior, ás marcas relativas a productos puramente hygienicos.

CouHin menciona sobre o assumpto duas importantes decisões judiciaes: uma do Tribunal Civil do Sena, de I9 de Junho de 1897 , que reconheceu ao A. Pearson a propriedade exclusiva da denominação Créoline; e a outra proferida pela Côrte de Paris, Camara Correcional, de 4 de Fevereiro de I897, a proposito da deminação Coricide, reclamada como sua propriedade exclusiva por GarnaUd (42).

35.-- Podem ser assignalados por marcas industriaes os productos da natureza, a saber-as producções da agricultura, da pecuaria, das minas?

\section{Porque não?}

Ainda que taes productos não sejam, propriamente, fabricados pelo homem, não deixam comtudo de ser um fructo da collaboração do seu trabalho; e esse trabalho constitúe uma industria (43).

Nessas condições, com que fundamento racional ou juridico restrigir-se á industria fabril (manufactu-

(42) Claude Counin, La Propriété Industrielle, Artistique et Litteraire, tom. III pag. 148 , not. I 227 .

(43) Umb. PIPIA, Nozione di Dirito Industriale, n. 248 , 2 ibi: «Dovendosi... intendersi la parola INDUSTRIA nel suo significato più largo e comprensivo, e quindi anche in quello di industria agricola, è superflua la specificazione della lege in ordine agli animali di razza, costituendo essz evidentemente un prodotto dell'industria agricola.» 
.reira ou machinofactureira) a applicabilidade das marcas industriaes? Não seria, quando menos, violentar arbitrariamente a natural significação da linguagem?

36. - A lei italiana, como vimos, menciona entre os objectos marcavers, além dos productos dá industria e os generos commerciaes, os animaes de alguma raça especial "gli animali di una razza a lui appartenente.»

Este accrescimo redundante, muito impugnado na elaboração parlamentar da lei, foi entretanto mantido no texto, por motivos circumstanciaes (44).

Opinam, todavia, os commentadores daquella lei que o pensamento do legislador foi antes ampliativo do que restrictivo, como se poderia deduzir por argumento de enumeratio incompleta.

37. - O direito francez amplia expressamente as garantias das marcas, dispondo no artigo 20 da citada lei de i 857: "Toutes les dispositions de la présente loi sont applicables aux vins, eaux de vie et autres boissons, aux bestiaux, grains, farines, et généralement à tous les produits de l'agriculture.»

38.--A lei suissa de i 890 , adopta, usando de formula menos prolixa, mas ainda sem obedecer a technologia scientifica, os mesmos principios do direito francez; pois estende a protecção das marcas aos "produits ou marchandises industriels et agricoles.»

39. - Mais avisado procedeu o legislador belga de I897, por occasião da discussão da lei de 6 de Abril daquelle anno. A's expressões do projecto, conservadas no texto definitivo "produits d'une industrie»,

(44) A.MAR, obr. cit. n. 35 . 
foi proposta a seguinte emenda additiva «. . et d'une exploitation agricole». Bem acceita como explicativa do pensamento da reforma, foi ella entretanto impugnada em nome do governo, sob fundamento de incontestavel valor juridico: Combatteu-a o ministro do Interior, ponderando que o vocabulo industria é comprehensivo de todo trabalho e, por isso, mais correcto; além disto, especificando-se na lei o trabalho agricola, poderia nascer a duvida se nella se comprehenderiam a horticultura, a exploração florestal, a mineração e outras industrias. Dada esta explicação, foi retirada a emenda, ficando entendido que as expressões «produits d'une industrie» abrangem os productos agricolas e os de todo trabalho industrial.

40.- A lei hespanhola de 16 de Maio de 1902 consignou em seu art. 23 a seguinte enumeração:

«Poderão fazer uso das marcas:

a) os agricultores, para distinguirem os productos da terra, das industrias agricolas, do gado e, em geral, de toda exploração agricola, flrorestal ou extractiva;

b) os fabricantes, para distinguirem os productos da sua fabrica;

c) os commerciantes, para determinarem os productos que elles compram para os venderem depois sob sua responsabilidade e garantia;

d) os artistas, para os productos elaborados no exercicio da sua arte, liberal ou mecanica;

e) aquelles que exercem uma profissão, para distinguirem os seus documentos pessoaes ou as suas producções intellectuaes ou manuaes.»

41.-Como se vê, figuram nessa disposição enumerativa producções artisticas, e intellectuaes. 
Pódem abrigar-se taes casos dentro da orbita da legislação brazileira?

Não vemos fundamento para resposta negativanem na lettra das nossas leis, nem no elemento logico da sua interpretação.

Quando um artista adopte uma certa marca figurativa para as producções da sua arte, quando uma empreza lithographica um embléma para os seus trabalhos, um jornalista uma denominação para a sua folha, um litterato ou scientista um pseudonymo para os seus escriptos: e o uso de taes marcas configurativas, symbolicas ou verbaes seja exercido com animo de dono: constituirá um acto licito o emprego por terceiros, para fins analogos, das mesmas figuras, symbolos, denominações e nomes?

E se se propuzer o artista, o lithographo, o jornalista, ou o homem de lettras - a effectuar o " registro do signal ou da palavra, revestido de todos os caracteres intrinsecos e extrinsecos prescriptos pela lei: poderá ser obstado de o fazer? Com que fundamento? Por não ser commerciante ou industrial, restricto sensu? Mas onde se preceitúa que taes vocabulos, o segundo sobre tudo, devem ser interpretados restrictamente?

42.-Somos de opinião que, por direito patrioł é marcavel tudo quanto póde ser objecto de commercio ou de industria, dado a esta palavra o seu sentido generico.

Não sómente não se oppõem a tal intelligencia as nossas leis sobre a propriedade industrial, artistica $\in$ litteraria, como tambem se cuaduna tal systema com a natureza dessa especialidade juridica.

As leis sobre marcas industriaes são, no conceito de Amar, leis de defeza contra os actos de desleal concurencia, leis de tutela do valôr adquerido pela ho- 
nestidade e pela capacidade industrial ou commercial, contra os abusos de terceiros; não instituem prerogativas, não liberalisam favores ou privilegios, mas sanccionam um direito natural, oriundo do exercicio da actividade humana. «Devesi perciò, conclue o illustre professor, ritenere que essa (a protecção legal) si applichi, ogniqualvolta un marchio si referisca ad un qualunque oggetto dell'industria o del commercio.» (45).

43.-Além desse argumento doutrinario, poderiamos tambem no direito patrio, para a intelligencia da palavra industria em relação ás marcas, invocar a autoridade da convenção de Paris de 20 de Março de 1883, promulgada no Brazil pelo Decreto n. 9233, de 28 de Junho de I 884.

Nesse documento diplomatico, no n. I do seu protocollo de encerramento, foi consignada a seguinte disposição interpretativa:

«As palavras propriedade industrial devem ser entendidas em sua accepção mais lata, no sentido de que se appliquem não só aos productos da industria propriamente dicta, mas egualmente aos productos da agricultura (vinhos, cereaes, fructas, gado etc. etc.) e aos productos mineraes entregues ao commercio (aguas mineraes etc.)»

\section{V.-Caracter essencial e caracteres accidentaes das marcas}

44.-Em que consiste essencialmente a marca? Quaes são os seus elementos substanciaes?

A nossa lei de 14 de Outubro de 1887 , textualmente reproduzida em seu artigo $2 .^{\circ}$, pelo artigo $2 .^{\circ}$ da de 24 de Setembro de I904, responde satisfacto-

(45) AMAR, obr. cit. n. 32. 
riamente, embora pelo methodo de exclusão, a essas perguntas.

Diz, com effeito, o duplo texto legal:

"As marcas de industria e de commercio podem consistir em tudo que esta lei não prohiba e faça differencar os objectos de outros identicos ou semelhantes, de proveniencia diversa.»

45.-Como se vê, empregou o legislador patrio, para determinar a noção de marca, o vocabulo da mais ampla significação possivel -tudo, limitando-lhe, embora, o alcance pela clausula restrictiva-que faca differençar os objectos, etc.

Assim, a condição essencial da marca, a sua substancia, consiste na aptidão para discriminar um producto de outros da mesma especie, mas de proveniencia diversa. A marca assignala a proveniencia do producto ou da mercadoria, opéra como a assignatura do industrial ou do commerciante sobre os seus productos ou as suas mercadorias (46).

$\mathrm{O}$ caracter essencial da marca consiste, portanto, em-marcar.

Varios, porém, são os modos de o fazer; e estes constituem outros tantos caracteres accidentaes das marcas.

46. - Não se póde conceber marca que não discrimine os objectos a que se destine; n'outros termos, não tem o caracter de marca, nem como tal póde ser admittido em direito,- - qualquer signal, forma ou palavra que, embora affecte a vista, o tacto ou a outiva, entretanto não sirva para extremar uns dos outros productos ou mercadorias similares, de origem diversa.

(46) A. Rennu, Codes de la Propriété Industrielle, vol. III, n. 5 I. 
47.-Dessa proposição não deflúe como collorario que a marca deva ser apparente.

Esta questão, foi, todavia, levantada a proposito das marcas habituaes do vinho de Champanhe impressas sobre as rolhas, na parte inferior ou lateral das mesmas, ficando assim, mais ou menos occultas, emquanto não são abertas as garrafas.

Embora seja necessaria esta operação para se verificar a existencia de taes marcas e assim a authentacidade do producto: nem por isso deixam ellas de realisar o seu fim essencial, a saber differençar os productos dos de outros productores.

São, por conseguinte, admissiveis as marcas não apparentes.

48. - E' certo que a marca apparente offerecerá superior garantia na generalidade dos casos, para os direitos do industrial ou do commerciante, pois advertiria os consumidores a cerca da origem dos productos. Mas, observa Pourllet, que importa este facto? Quem é que perde com a dissimulação da marca, a não ser o proprietario della? (47).

A mesma duvida foi suscitada a proposito das marcas consistentes em papeis rendilhados que os confeiteiros costumam collocar nas bocetas de dôces, e ficam, portanto, na parte interior das mesmas.

Ambos esses casos foram objecto de julgamento dos tribunaes francezes, que firmaram arestos no sentido da legalidade de taes marcas (48).

49.--Comporta a nossa legislação patria a elasticidade desta doutrina?

(47) Povlllet, obr. cit., n..$^{\circ} 2$.

(48) Pouillet, obr. cit., n. ${ }^{\circ} 2$. 
Não temos duvida em responder pela affirmativa.

Observaremos, comtudo, que a recente reforma de 24 de Setembro de I904, no provavel intuito de consignar uma disposição ampliativa, e remover uma obscuridade aliás imaginaria, veio, ao contrario, suscitar sobre este ponto alguma difficuldade.

Assim, tendo reproduzido litteralmente o artigo $2 .^{\circ}$ da L. de I4 de Outubro de I887, accrescentoulhe o seguinte:

«§ unico. As marcas podem ser usadas tanto nos artigos, directamente, como sobre os recipientes ou envolucros dos ditos artigos.»

A nos attermos á lettra deste texto, poderiamos' nas hypotheses precedentes, considerar como recipientes as rolhas das garrafas, e envolucros os papeis rendilhados das bocetas de confeitos? E' duvidoso.

Eis ahi está o inconveniente do systema de enumerações em preceitos legaes!

Todavia, de accordo com o pensamento do legislador e sem mesmo violentar o texto, parece-nos con ${ }^{-}$ forme a direito comprehender como appendices das garrafas, e portanto parte integrante dos recipientesas rolhas; e appendices das caixinhas de confeitos, e envolucros tambem, - os papeis rendilhados.

50.-Alguns productos não são susceptiveis, pela sua propria substancia, de receberem directamente outras marcas, a não serem as nominaes. Nestes casos, as marcas figurativas collocam-se sobre os envolucros ou recipientes. Assim accontece em relação ás bebidas e quaesquer outros liquidos, aos productos em pó, em grãos, ou em outro estado tal que não permitta uma fórma estavel, independentemente de envolucro ou recipiente. 
51. - Inversamente, em relação a outros productos, nem é necessaria a apposição de marca; pois esta póde consistir em certa fórma original dada ao mesmo producto, quando este seja solido, tenha dimensões sufficientes e a necessaria consistencia.

O mesmo systema póde ser applicado aos recipientes e envolucros de productos liquidos, ou não susceptiveis de fórma estavel e consistente.

52.-Multiplas e variadissimas são as modalidades de que se revestem as marcas. Cada uma dessas modalidades, compostas de um ou mais elementos, constitue outros tantos caracteres accidentaes das marcas. Havemos de estudal-as nas secções seguintes.

O unico requisito invariavel, aquelle sem o qual perde a marca o seu caracter essencial, e que, conseguintemente, fórma a propria substancia da marca: é, como temos visto,-a sua propriedade de differençar os objectos a que se destina, assignalando-lhes a procedencia. Sómente assim, repetimos a nossa expressiva tautologia:-a marca marcará.

\section{VI.-0 que póde constituir marca}

53.-Acabamos de mencionar qual o caracter essencial e quaes os caracteres accidentaes das marcas de industria e de commercio.

E’ da substancia da marca - a aptidão para differençar os objectos. Pouco importa que esta differenciação rezulte da fórma dada aos productos ou a qualquer dos seus accessorios, da côr, do aspecto de uma parte, de varias partes, ou do conjuncto; de combinações diversas, de quaesquer signaes e denominações: comtanto que ella individualise a producção ou a mercadoria. 
E', portanto, esta ultima condição constante, e não aquelles elementos varios e mutaveis, $-o$ que caracterisa fundamentalmente a marca.

54.-A nossa lei de 23 de Outubro de 1875 , seguindo, aliás, a licção que já expuzemos e criticámos, da jurisprudencia estrangeira, fazia consistir as marcas de industria e de commercio-nos signaes adoptados por qualquer fabricante ou negociante para os productos da sua manufactura e do seu commercio, para os tornarem distinctos dos de qualquer outra procedencia.

Já mostrámos, precedentemente, que a expressão signal é defeituosa, por muito restrictiva, porque não abrange, quando menos, as marcas verbaes.

Melhor inspiração tiveram os legisladores de I 887 e de I904, eliminando da noção legal de marca aquella expressão - signal, e a substituindo por - «tudo».

Assim, nos termos do nosso direito vigente,- tado póde ser marca de industria e de commercio; tudo, com duas restricções apenas: tudo a) que a lei não prohiba, e b) que faça differençar os objectos segundo a procedencia delles.

Ambas as leis accrescentam iisdem verbis:

"Qualquer nome, denominação necessaria ou vulgar, firma ou razão social e as lettras ou cifras sómente servirão para esse fim revestindo fórma distinctiva,»

Veremos, adiante, o alcance das expressões finaes desta disposição.

55.— «Tudo que faça differençar os objectos....», diz o legislador patrio,-póde ser adoptado como marca de industria ou de commercio. Portanto, uma fórma que não seja a habitual dos productos similarespóde ser objecto de marca. 
Qual, porém, o criterio seguro para se determinarem as fórmas aptas para servirem de marca, e as imprestaveis para tal fim?

A esta interrogação não é licito responder-se senão em these; fazemol-o, pois, de accôrdo com Counin: "Lorsque cette forme' est telle qu'elle caracterise nettement le produit et qu'elle est de nature à le distinguer des produits similaires, il est manifeste quelle constitue une marque de fabrique ou de commerce dans toute l'accéption du mot.» (49)

Faz-se, portanto, necessario que a fórma adoptada para marca seja nova e especial; de modo nenhum a fórma commum, e ainda menos a fórma necessaria, dos productos congeneres. (50)

As mesmas considerações attinentes á fórma dos productos são applicaveis á dos seus receptaculos. (5 I)

Assim, nada se oppõe a que algum industrial adopte como marca dos seus ptoductos uma fórma especial caracteristica para os respectivos recipientes. Exemplos: as garrafas com dois bojos, do licôr Pi. perment, a fórma de barril dos frascos de mostarda de Louit as botijas da genébra de Fookin, etc.

56.-Baseadas em argumentos de facil refutação, algumas duvidas tem sido suscitadas sobre a aptidão da fórma dos productos ou dos seus recipientes e envolucros para constituirem marcas de fabrica. MaILLARD DE Marafy expõe-nas e, elle mesmo, as combate victoriosamente illustrando a sua argumentação com importantes arestos dos tribunaes. (52)

(49) Couhin, obr. cit. tom. III, pag. 197 e I99, e not. 1270.

(50) Armengaud Ainé, Marq. de Fabr. pag. 13.

(51) Ruben De Couder, Suppl. au Dict. de Droit Comm, tom. II, V.: «Marque de fabrique» n. 29.

(52) MALLLARD DE MARAFY, obr. cit. V. «Forme». 
A generalidade das expressões (los nossos textos legaes não permitte, no direito patrio, qualquer contestação a esse respeito. (53)

57.--Se uma determinada côr dada ao producto, ao seu involucro ou recipiente, ou aos seus rotulos etiquettas, chapas, capsulas, medalhas etc., póde constituir de per si marca de industria ou de commercioé objecto de graves controversias.

Pela negativa se pronuncia a opinião predominante, fundada neste argumento: sendo limitado o numero das côres, se ellas fossem admittidas como marcas de fabrica, rezultaria desse facto--constituir-se, em mãos de poucos, um monopolio industrial ou commercial; pois, registradas como marcas privativas todas as côres: só ficariam livres e no dominio commum a producção e o commercio de productos e mercadorias que fossem incolores!

58.-Se a objecção é mais ou menos procedente em relação á côr, abstracção feita da sua collocação em determinados lugares, de desenhos variados ou simplesmente de pontos e linhas coloridas: ella não prevalece quando se dão taes circumstancias.

Não prevalece ainda, e com razão maior, desde que consista a marca não n'uma só côr, mas n'uma combinação de côres, que the dê uma apparencia original, caracteristica. (54)

(53) Além dos textos, já por nós mencionados, do art. $29^{\circ}$ da Lei n. I 236 de 1904 , e $2 .^{\circ}$ da Lei n. 3346 de 1887 , oppõe-se ainda áquella interpretação restrictiva-o art. I9 do Decreto n. 5424 de Io de Janeiro do corrente anno; $i b i$, a formula imperativa: "Será admittido a registro como marca de industria e de commercio tudo aquillo que a lei não prohiba, e faça differençar o objecto de outros identicos ou semelhantes de proveniencia diversa etc.»

(54) Maillard de Marafy, obr. cit. Verb. «Couleur», n. 6. 
59.-O Decreto n. ${ }^{\circ} 5.424$ de ro de Janeiro de I 905, que regulamentou a Lei n..$^{\circ}$ I. 236 de 24 de Setembro de 1904, contém neste ponto uma verdadeira exorbitancia; pois, transgredindo da sua esphera constitucional, accrescentou o poder executivo a seguinte innovação, contraria ao texto legal, no art. I9 $\S 2 .^{\circ}$ do regulamento:

«O tamanho e as côres, por si só, não podem constituir marca de fabrica e de commercio.»

Não é esta, segundo a jurispruđencia universal e a licção dos mestres, a doutrina verdadeira; e sim a que acabamos de expôr. Não é tão pouco esta a expressão do nosso direito patrio, segundo o qualé marca, e nesse caracter, tem que ser admittido a registro - «tudo que a lei não prohiba e faça differençar os objectos etc.» Ora, qual é a lei que prohibe a adopção de côres como marcas industriaes? $\mathrm{E}$ desde quando não servem ellas para differençar os objectos, nos termos da legislação citada?

60.-O aspecto geral do producto e a sua feição de conjuncto, originada de todos os seus signaes caracteristicos, o individualisam, assim como a physionomia discrimina os homens.

Dest'arte, cada um dos signaes componentes dessa marca complexa pode, de facto, considerado isoladamente, carecer de novidade; entretanto, o aspecto geral revestir-se-á, talvez, de certa originalidade. E assim, realisando o objectivo legal de differençar os productos, deverá a marca ser admittida a registro.

61. $-E^{\prime}$ frequente nas imitações illicitas de marcas, não se deparar entre a marca legitima e a fraudulenta nenhuma parte absolutamente egual, sendo manifesta, todavia, entre ellas a semelhança do aspecto geral. 
Em tal conjunctura, mal andaria o auctor da marca imitativa, se pretendesse obter o registro da mesma; pois, ella não estaria nas condições de merecer o amparo da lei, por isso que, na hypothese figurada, não discriminaria sufficientemente os objectos sobre os quaes se applicasse-de outros de procedencia diversa, a saber dos do industrial ou commerciante proprietario da marca imitada.

62. - O nosso legislador não menciona expressamente entre as marcas -os signaes, ou quaesquer signaes, como quasi todas as legislações dos outros povos cultos. E' certo, porém, que elle empregou uma formula mais ampla, «tudo que faça differençar etc.»

Aquellas expressões, não obstante, figuram no Decreto de ro de Janeiro de rgo5.

Além disso, a enumeração da Lei n. ${ }^{\circ}$ r.236 de I 904 não é taxativa, mas apenas exemplificativa.

Isto mesmo foi declarado no art. I9 $\S \mathrm{I} .^{\circ}$ do citado Decreto de I905, o qual, tendo reproduzido textualmente a disposição da lei, accrescentou:

«A enumeração feita neste artigo é puramente enunciativa ou exemplificativa e não taxativa, podendo a marca de industria e de commercio ser constituida por todo e qualquer signal ou meio material capaz de differençar os objectos de outros identicos ou semelhantes de proveniencia diversa...»

63.-Quaes são, porém, esses signaes a que se refere o decreto regulamentar? Está no proprio texto a resposta:-São todos os signaes-Distinctivos ou, litteralmente,- «todo e qualquer signal... CAPAZ DE DIFFERENÇAR Os OBJECTOS etc.»

Nesta generalidade comprehendem-se, por conseguinte, a despeito das hesitações de alguns juriscon- 
sultos e de certa vacillação na jurisprudencia estrangeira e tambem, em parte, na do Brasil,_as lettras, algarismos, palavras, combinações de côres, brazões, retratos de chefes de Estados e de homens e mulheres celebres, e as decorações, sem fallarmos nos symbolos, emblemas, desenhos, plantas topographicas, figuras geometricas, que constituem, propriamente, as marcas figurativas. (55)

64. - Em relação ás diversas modalidades de que se revestem os signaes distinctivos, e que parecem susceptiveis de se multiplicarem ao infinito, tem a legislação positiva imposto certas restricções, exigindo, para que alguns desses signaes possam ser registrados como marcas de industria ou de commercio, determinadas condições.

Veremos adiante quaes são sobre tal ponto as resalvas e as exigencias prescriptas pelo direito patrio.

65. - Entre os signaes distinctivos cabe, pela sua importancia, o primeiro lugar ás figuras ou mais geralmente aos signaes figurativos. $\mathrm{E}$ a razão nol-a dá Maillard DE MARAFx: "Le signe figuratif, diz elle, est la marque internationale par excellence, car il parle aux yeux et est compris sur tous les points du monde, quelle que soit la langue de l'acheteur.» (56)

Não sómente o signal figurativo falla a mesma linguagem a todos os povos, sem embargo da diver-

(55) MAILlaRd DE MARAFע, obr. cit. verb.: «Signes. Distinctifs».

(56) Maillard DE Marafy, obr. cit. verb.: «Signes Figuratifs». E' conhecida e afamada no mundo inteiro a marca do rum da Jamaica que traz dentro de um losango sob fundo vermelho uma cabeça de negro. Pois bem, nesta marca que é complexa, visto comprehender além da mencionada figura, a denominação ou marca denominativa "Black head rum», os nomes commerciaes de procedencia "Kingston» e «Jamaica» e a firma social W. S. Wood \& Comp., o que mais impressiona os sentidos e a memoria-é, incontestavelmente, a parte figurativa, a saber - a cabeça de negro.

$\mathrm{E}$ tanto é procedente o nosso reparo, que este elemento da marca tem sobrepujado os outros, a ponto de os supplantar no giro commercial, dando de per si o nome ao producto, que é conhecido vulgarmente pela designação«rum cabega de negro». 
sidade dos idiomas, como tambem impressiona, no proprio paiz de origem dos productos marcados, a vista mesmo dos analphabetos: o que não se dá, em gráo de egualdade, com as marcas verbaes. E assim, adiquirem aquellas incontestavel preponderancia, em consequencia da generalidade dos seus effeitos.

66.-Uma ou mais palavras, uma phrase, um distico-podem igualmente servir para marca de industria ou de commercio.

$\mathrm{Ou}$ figuram conjuntamente com outros elementos, e serão parte de uma marca mixta, complexa; ou constituem marca de per si, independentemente de outros elementos, e formarão, neste caso,-marca verbal.

Quando a palavra adoptada tem por fim designar o producto, e assim differençal-o, pelo nome, de outros productos simulares de procedencia diversa, então ella toma o caracter de marca ou denominação.

67.-Para que as palavras ou as denominações constituam, desaccompanhadas de outros elementos, marcas industriaes, faz-se necessario, segundo a legislação patria, que se revistam de fórmas distinctivas.

Esta mesma exigencia comprehende as firmas ou razões sociaes, as lettras e os algarismos. (57)

Não alcança, entretanto, as denominaçoses de phantasia; (58) por isso que o texto legal sómente se re-

(57) Lei n. 1236 de 1904 cit., art. $2 .^{\circ}$, segundo periodo: «Qualquer nome, denominação necessaria ou vulgar, firma ou razão social e as lettras ou cifras sómente servirão para esse fim revestindo fórma distinctiva.»

(58) Poulllet, obr. cit., n. 46, dá a seguinte noção de denominação de phantasia : «La dénomination arbitraire ou de fantaisze est celle qui, créée ou non par le fabricant, n'éveille pas forcément l'idée de l'objct auquel elle s'applgue, qui ne ressort ni de la nature ni du genre de l'objct, si indépendante en un mot du produit lui-même qu'il puisse étre reconnu et désigné sous un autre nom. Elle consistera soit dans un mot nouveau que le fabricant aura forgé paur la circonstance, sont dans un mot dejà connu, maîs n'ayant le plus souvent aucun rapport avec le produit qu'elle désigne...» 
fere ás denominaç̃es necessarias ou vulgares dos productos aos quaes as marcas se destinem.

E' racional esta isenção. Com effeito, as denominações de phantasia tem já, por sua natureza, uma fórma distinctiva, embora esta não seja graphica, e sim phonica. (59)

\section{VII.—0 que não póde constituir marea}

68.-Se é apto para constituir marca tudo que serve para differençar os productos ou mercadorias, assignalando-lhes a procedencia natural, industrial ou mercantil; pode-se inferir, invertendo-se a proposição, que:-não constitúe marca o que não discrimina, uns de outros, objectos congeneres de origem diversa.

A esta primeira exclusão, oriunda do proprio caracter substancial da marca, additam-se duas outras, resultantes de prohibições legaes expressas ou implicitas.

(59) Tanto é procedente o nosso reparo que, sempre que acontecer que a denominação de phantasia não discrimine sufficientemente o producto, podendo, ao contrario, induzir a confusão delle com outro de procedencia diversa,-não deverá ser acceita como marca de fabrica. Além de varios arestos neste sentido, mencinados por PouIllet, MaIllard DE MARAFY, Darras e nas Pandectes Françaises, precioso repertorio de jurisprudencia, dirigido por ANDRÉ WeIs. Encontramos no fasciculo de Setembro e Outubro dos Annales de la Propriété Induslrielle, de J. Patallle, importantes decisões do Tribunal do Sena de 7 de Fevereiro de 1902 e de mais oito tribunaes francezes condemnando como imitações illicitas as denominações «Aux Planteurs Javanais» e outras contendo a palavra Planteur, applicaveis a café ou a chá, por isso que são susceptiveis de produzir confusão com a marca de commercio « $A u$ Planteur», de propriedade de PRÉvosT \& FILS, importadores dos mencionados productos.

Encontra-se presentemente nesta praça uma marca de vinho do Porto que traz a denominação «Mathusalem», a marca symbolica de um patriarcha velhissimo porém muito robusto, tendo a seus pés um leão e mostrando um calix de vinho. Circula estas figuras o seguinte distico, que é marca verbal: «Este é o segredo da minha força». Vem no mesmo rotulo o nome commercral «Especialidade de Manoel da Costa Oliveira». Composta de tantos elementos, esta marca é-complexa ou mixta. 
69.-As prohibições expressas são catalogadas no art. 8 da Lei n. ${ }^{\circ}$ I.236 de 24 de Setembro de I 904. (60)

Occupa entre ellas o primeiro lugar as «armas, brazões, medalhas ou distinctivos publicos ou officiaes, nacionaes ou estrangeiros, quando para seu uso não tenha havido autorisação competente.»

Obtida, portanto, pelo registrante a competente autorisação para o uso de taes emblemas em suas marcas de industria ou de commercio. cessa a prohibição legal.

70. $-\mathrm{E}$ ' manifesto que os qualificativos «publicos ou officiaes, nacionaes ou estrangeiros» desse texto referem-se a todas as especies nelle mencionadas, a saber:-armas, brazões, medalhas ou distinctivos; e não sómente á ultima-distinctivos.

Desta observação resulta que não é vedado, ainda sem autorisação, o registro de marca consistente em armas, brazões ou medalhas, que não sejam publicos

(6o) Esse texto, que è a reproducção litteral do art. 8 da Lei n. 3346 de 14 de Outubro de 1887 , assim dispõe: tir em:

"Art. $8{ }^{\circ}$ E' prohibido o registro de marca que contiver ou consis-

I. armas, brazões, medalhas ou distinctivos publicos ou officiaes, nacionaes ou estrangeiros, quando para seu uso não tenha havido autorisação competente ;

$2 !^{\circ}$ nome commercial ou firma social de que legitimamente não possa usar o requerente;

$3 .^{\circ}$ indicação de localidade determinada ou estabelecimento que não seja da proveniencia do objecto, quer a esta indicação esteja junto um nome supposto ou alheio, quer não;

$4 .^{\circ}$ palavras, imagens ou representações que envolvam offensa individual ou ao decoro publico;

especie;

$5 .^{\circ}$ reproducção de outra marca já registrada para objecto da mesma

6. imitação total ou parcial de marca já registrada para producto da mesma especie, que possa induzir em erro ou confusão o comprador. Considerar-se-á verificada a possibilidade de erro ou confusão sempre que as differenças das duas marcas não possam ser reconbecidas sem exame attento ou confrontação.» 
ou officiaes. Tal accontece em relação aos distinctivos e é expresso no texto legal. (6I)

Não é vedado o registro de alheias armas, brazões, medalhas ou distinctos particulares - como marcas ou parte de marcas industriaes. Não é vedado, mas não se segue que o acto seja regular e, menos ainda, juridico.

O que, tão sómente se affirma é que-de tal facto, embora irregular, não rezulta infracção de relaçø̃es de ordem publica (62). Não significa isto que o particular, offendido em seus direitos pela violação da sua propriedade immaterial, fique desarmado de recursos para a sua defeza.

Tem elle ao seu alcance a protecção do direito commum. (63)

71.-E' tambem vedado, por expressa disposição legal, constituirem marca ou della fazerem parte os

(6I) Esta illação é corroborada pela disposição do art. 355 do Codigo Penal, reproduzida pelo art. I4 da cit. Lei n. i236 de r904, que comina pena sómente contra o uso, sem autorisação competente, em marca de industria ou de commercio, de armas, brazões etc. publicos ou officiaes, nacionaes ou estrangeiros.

(62) Esta doutrina é corroborada pela Convenção de Paris, de 20 de Março de 1883 , á qual nos temos referido. No final do n. 4 do seu Protocollo de encerramento foi incluido o seguinte: «Para evitar qualquer falsa interpretação, fica entendido que o uso dos brazões publicos e das decorações póde ser considerado como contrario á ordem publica, no sentido do paragrapho final do art. $6 »$.

O periodo a que se faz remissão é este:

«O deposito (da marca) poderá ser recusado, si o objecto para o qual elle foi pedido, for considerado como contrario á moral ou á ordem publica».

(63) Admittindo que da prioridade do uso, e não do facto do registro, resulta a propriedade da marca; e que o registro é apenas declarativo e confirmativo, mas não attributivo da propriedade da marca: decorre como consequencia-que o registrante de marca industrial, como de qualquer outra alheia. propriedade, material ou immaterial,-não registra um direito, mas a sua propria culpa. Elle authentica a prova do seu delicto ou quasi delicto.

Ainda que no nosso direito publico tenham sido abolidos os fóros de nobreza e os titulos nobiliarchicos (Constituição da Republica, art. $72 \S 2 .^{\circ}$ ), ainda assim, póde-se conceber que os titulos, quando continuem a ser usados, tenham a protecção legal, meramente como nomes civis, quaes os appellidos patronimicos. 
nomes commerciaes ou frmas sociaes de que legitimamente não possam usar os registrantes. (64)

Chama-se nome commercial, que, como adiante veremos, não se deve confundir com denominação commercial, -o nome:

a) do commerciante e, por synedoche, do industrial, seja pessoa natural ou pessoa juridica; industrial e

b) do estabelecimento commercial ou empreza

c) do lugar da proveniencia do producto ou mercadoria. (65)

Ainda que seja esta a doutrina predominante na jurisprudencia estrangeira, todavia, o direito patrio não considera, propriamente, como nomes commerciaes as especies acima enumeradas sob as lettras $b$ e $c$. Tanto assim, que as violações de uma e de outra constituem figuras juridicas differentes, com differentes cominações penaes. (66)

72.-Prohibe o direito patrio o registro de marcas contendo nome commercial ou firma social de que legitimamente não possa usar o registrante. Perguntamos, porém,-quid juris em relação aos casos em que:

(64) Lei cit. n. I 236 de Iyo4, art. 8 n. 2.

(65) Rent BARBIER, De la Concurrence déloyale, pag. 70 ; JAMEs Valloton, La Concurrence deloyale.-Du nom commercial $\S 39$.

(66) A violação do nóme commercial incide na sancção do art. I3 n. 9 da Lei n. I236 de I904, cuja penalidade consiste em "prisâo de seis mezes a um anno e multa a favor do Estado, de 500\$ a 5:000\$》; á medida que a mesma lei, em seo art. I4, pune com as «penas de multa de Ioo\$ a 5oc\$ em favor do Estado» o uso de marca com indicação de localidade ou estabelecimento diverso do da proveniencia da mercadoria ou producto.

A mesma distincção rezulta da confrontação dos arts, 8,9 e ro da Convenção de Paris de 20 de Março de 1883 , promulgada no Brasil pelo Decr. n. 9233 de 28 de Junho de 1884 ; e ainda dos arts. 89 lettras $b$ e $c$ P. IV do Decr. n. 3084 de 5 de Novembro de 1898 ; e finalmente do art. 8 ns. 2 e 3 da recente lei n. 1236 de 1904. 
I. o nome civnl do registrante seja identico ao de industrial ou commerciante já acreditado no mesmo ramo de industria ou de commercio que elle se proponha a explorar;

$2 .^{\circ} \quad$ o registrante tenha transferido a outrem com o fundo de commercio o seu nome commercral, identico ao civil.

E' nosso parecer, quanto ao primeiro ponto, que o commerciante ou industrial pode, em regra, usar no commercio do seu nome civil, ainda mesmo existindo já nome commercial identico (67); mas não poderá adoptal-o para marca nominal dos seus productos ou mercadorias, nem incluil-o nas suas marcas de industria ou de commercio. (68)

Quanto á segunda questão, affirmamos que-os termos do contracto farão lei entre as partes. Assim, se a cessão do nome foi incondiccional e sem restric-

(6\%) H. Allart, De la Concurrence déloyale, n. 20: «DROIT DE L'HOMONVME À L'USAGL DE SON NOM. - Si le commerçant ou l'industriel ne peut usurper le nom d'un concurrent, il a taujours le droit de faire usage de son propre nom dans l'cxercice de son commerce ou de son industrie. Ce droit subsiste même dans le cas ou une aulre personne, ayant le même nom serait antérieurement établie et exploiterait depuis longtempo le mème commerce. Sans doute l'existence de ces deux établisssements dans une même localuté, peut être la cause de confusions et d'erreurs regrettables. Mars cette considération n'est pas suffisante paur dêpouiller une persoune du droit qui lui appartient de faire usage de son nom. D'autre part on ne saurait, sans porter la plus grande atteinte à la liberté d'industrie, lui interdire d exerceer le commerce qui lui convient. D'ailleurs les tribunaux sont là pour réprmer les abus et pour ordonner telles mesures qu'ils jugeront nécessaires pour prévenir le préjudice pouvant résulter de la similitude des noms.»

A restricção que estabelecemos no texto tem por fito precaver os casos de fraude: quando por exemplo o homonymo é apenas um homem de palha, adrede procurado para acobertar com o seu nome interesses de terceiros, em detrimento dos direitos do seu homonymo, industrial ou commerciante acreditado.

(68) O uso do nome civil no commercio ou na industria é o exercicio de um direito absolut's, originario, do homem: $O$ mesmo não se dá em relação á propriedade da marca industrial.

Esta é o effeito de um direito hypothetico ou derivado, a saber-rezultante de um acto, - a invenção ou a occupação e subsequentemente - o registro da marca. Não ha, portanto, paridade quanto ao caracter juridico de um e outro desses direitos. 
ções, ella importa necessariamente a perda delle--para os fins da exploração do mesmo ramo de commercio ou de industria. Se isto mesmo expressamente se estipulou, então--tollitur qucestio.

No caso em que a cessão se reveste apenas do caracter de uma permissão do uso do nome pelo cessionario, fica implicita a reserva de egual direito para o cedente.

73. - Chama-se frrma social ou tambem razão social o nome sob o qual uma sociedade mercantil ou industrial exerce o commercio ou a industria e se assigna nos actos respectivos. (69)

A firma social é, pois, um nome commercial. Como especie deste genero, são-lhe outhorgadas pelo direito patrio as mesmas garantias que ao nome commercial.

74.-A's palavras «nome commercial ou firma social» accrescenta o texto: «... de que legitimamente não possa usar o requerente.»

Nestes termos, não podem ser dados a registro por um industrial ou commerciante como parte de sua marca:

a) nome ou firma alheios, sem a competente autorisação do dono;

b) nome ou firma diversos do de que elle usa, salvo se, não tendo elles dono e tambem não estando no dominio commum, o registrante os adoptar, satisfeitas as prescripções legaes; (70)

c) o seu proprio nome civil, se identico ao nome commercial ou industrial que elle tenha cedido a outrem sem reserva de direito para si.

(69) E' essa a definição dada no art. $2 .^{\circ}$ do Decreto n. 916 de 24 de Outubro de 1890 ; Souza PinTo, Diccionario de Legislafão Commercial, $\mathbf{n}$. 2597.

(70) Lei n. 1236. do 24 de Setembro de 1904, arts. 5, 7 e 9. 
75. - Passemos ao terceiro caso de impedimento legal para registro de marca, a saber-quando haja nella "-indicação de localidade determinada ou estabelecimento que não seja o da proveniencia do objecto, quer a esta indicação esteja junto um nome supposto ou alheio, quer não.»

Os nomes de localidades e de estabelecimentos são, como dissemos, equiparados, para certos effeitos juridicos, ao nome commercial. $\mathrm{O}$ uso delles, como indicação de proveniencia-não pode ser tolerado em marcas destinadas a productos ou mercadorias de outra procedencia. Em tal caso, a tolerancia equivaleria a uma connivencia do legislador n'uma fraude prejudicial aos consumidores e lesiva dos direitos dos productores. Viria, em certos casos, offender os interesses legitimos de estabelecimentos industriaes ou casas commerciaes, de lncalidades reputadas pela excellencia de certos productos ou de toda uma região ou um paiz, onde condições naturaes ou o aperfeiçoamento alcançado pelo esforço humano em certos ramos de industria the tem grangeado tradicionalmente indisputavel primazia no conceito universal em relação a determinados productos. (7 I )

(7 I) Quem póde contestar a fama de que gozam em todos os mercacados do mundo em razão da sua procedencia, por exemplo, os seguintes productos: os cafés de Moka, de Java, de S. Paulo, o chá do Ceylão, o cacáo do Pará, a borracha do Amazonas, a porcellana do Japão e de Sevres, a seda da China e de Lyão, os vinhos de Tokai, da Champanha, de Bordeaux, da Borgonha, da Mosella, do Porto, de Xerez, da Madeira, as rendas de Valenciennes, a cutellaria de Tolosa, o azeite de Lucca, o rum da Jamaica, o cognac de Cognac, os relogios de Genebra e de Londres. a perfumaria de Paris, os presuntos de York e da Westphalia, as aguas mineraes de Vichy e de Saint Galmier, etc. ? E em todo o Brasil, não são geralmente reputados como excellentes, tambem em razão da sua origem : a aguardente de Paraty, os queijos e o toucinho de Minas, o arroz de Iguape, as aguas mineraes de Caxambú e Lambary, o assucar de Pernambuco, o fumo da Bahia e de Groyaz, o matte do Paraná, o xargue do Rio Grande ? E em razão da sua procedencia de afamados estabelecimentos industriaes, gozam incontestavelmente de grande apreço nos mercados de consumo nacional, por exemplo, os comestiveis da Fabrica do Paredão, em Pelotas, o chocolate do Moinho de Ouro, no Rio, a cerveja da Antarctica, em S. Paulo, etc. etc. Não proseguimos na enumeração para não estarmos a fazer preconicios não encommendados. 
76. - Com razão reprime o direito taes factos, já obstando o registro de marcas nessas condições, já, quando usadas independentemente de registro, concedendo aos prejudicados acção criminal para a punição do delicto, e acção civil para a satisfação do damno causado; e ainda diligencias de busca, apprehensão e deposito, ou destruição dos objectos revestidos de taes marcas, e prisão em flagrante daquelles em cujo poder os mesmos se encontrem. (72)

77.-O art. $80^{\circ}$ da Lei n. ${ }^{\circ}$ I 236 prohibe, em quarto lugar, nas marcas "palavras» imagens ou representações que envolvam offensa individual ou ao decoro publico.»

Quanto ao registro originario e, em geral, ás marcas nacionaes, nenhuma difficuldade pode suscitarse da execução deste preceito legàl. Se, porém, a marca empregada, ou aquella cujo deposito se pretender, fôr estrangeira e houver sido já registrada, tal qual, em seu paiz de origem: será ella passivel de repressão no Brasil, ou se lhe poderá recusar o solicitado registro, quando nos casos do $n .^{\circ} 4 .^{\circ}$ deste art. 8. da Lei?

Pensamos que não.

(72) Lei cit. n. 1236 de 24 de Setembro de I904, arts. 20 a 28.

Pois bem, seria honesto, seria justo, deveria ser tolerado-que o importador do café do Mexico, do café de Venezuela ou Costa Rica marcasse as suas saccas com a denominação Café Moka, ou Café S. Paulo, e os typos inferiores Cafe do Brasil, á medida que os importadores do café brazileiro os vendem sob outro nome commercial? Que os vinhos nacionaes trouxessem como a designação de procedencia-Bordeaux, Rheno ou outra? Que nas garrafas de aguas mineraes artificiaes, ou mesmo naturaes de outras fontes, se inscrevessem as designações-Vichy, Caxambú, Lambary etc.? Que uas latinhas de chá do Murumby figurassem como designações de procedencia-Shang-hai, Ceylão ou Singapura? Que os presuntos preparados na rua Formosa em S. Paulo trouxessem a designação Copland? Que os recipientes da cerveja da Penba fossem marcados com nome Anthartica? Finalmeute, que o sapateiro da esquina assignalasse o calçado da sua fabricação com as marcas Clark ou Casa Rocha?! $\mathrm{Ha}$, portanto, muita razão em se considerarem taes factos como delictuosos; por isso, tambem, a lei os reprime penalmente. 
Embora, ex vi do art. 6 da Convenção de Paris de 20 de Março de 1883, não se possa recusar deposito e protecção legal ás marcas registradas nos paizes de origem. fazendo elles parte da União Internacional para a proteç̧ão da propriedade industrial, não obstante, esse deposito não é obrigatorio se, a criterio da administração incumbida do registro, a marca fôr considerada como contraria á moral ou á ordem publica. (73)

Em tal caso além de se the recusar o registro da marca, incorrerá em disposições penaes aquelle que usar della. (74)

78. - E' tambem prohibido o registro, nos termos do n..$^{\circ}$ do cit. art. $80^{\circ}$ da Lei n..$^{\circ}$ I 36 , quando consiste a marca na «reproducção de outra marca $j a ́ a$ registrada para objecto da mesma especie.»

Sobre a materia desta disposição occorrem-nos dois reparos:

I. Não é vedado o registro de marca que reproduza total ou parcialmente marca alheia ño registrada. Os textos do art. $8 .^{\circ}$ n. $5^{\circ}$ e art. I 3 n.. 5 não deixam duvida a tal respeito.

E' certo, porém, que ao prejudicado pela reproducção de marca sua legitima, embora não registrada, cabe contra o usurpador acção civil de indemnisação. (75)

(73) Eis o que dispõe o citado art. 6 da Convenção de Paris :

"Toda marca de fabrica ou de commercio regularmente depositada no paiz de origem será admittida a deposito e protegida tal qual em todos os outros paizes da União.

O deposito poderá ser recusado, se o objecto para o qual fôr pedido fôr considerado como contrario á moral e á ordem publica.»

(74) Codigo Penal, arts. $355 \S 1 .^{\circ}$ e 320 § 2; LeI n. 1236 de 1904 arts. 14 e 15.

(75) LeI n. I236 de 1904 art. 18 . O registro da marca lhe é necessario para amparal-a com as garantias especiaes das leis sobre marcas industriaes. A falta delle, portanto, se priva o dono da marca dessa protecção 

especie.»

2." Diz-se no texto «...para objecto da mesma

Effectivarnente, a propriedade sobre a marca não ten um caracter absoluto, senão restricto á sua applicação. Assim, o direito do proprietario é exclusivo, sómente em relação a productos da mesma especie.

79. - Uma vez que a importancia da marca origina-se, não dos seus elementos intrinsecos, mas da sua applicação, a qual tem por fim distinguir productos congeneres, authenticando-lhes a proveniencia: é manifesto que a applicação da mesma marca a productos de especies differentes-nenhum inconveniente pode acarretar.

Desde que este facto não induz o comprador a confundir especies differentes, por terem a mesma marca, não haverá na reproducção desta a) nenhum damno para o proprietario da marca, nem tão pouco b) nenhum dolo por parte do reproductor ou imitador da mesma.

$\mathrm{E}$ assim, perante o direito civil, fallece, na pri. meira hypothese, um dos elementos essenciaes para a acção de indemnisação-a existencia de damno causado; e em face do direito criminal, no segundo caso, não é punivel o facto, pois não se concebe nelle o dolo, que é condição elementar de todo delicto, nos termos do art. 24 do Codigo Penal. (76)

supplementar, todavia não o priva das garantias do direito commum. Ora, no caso vertente, sendo o registro, como vimos, apenas declarativo e comprobativo da propriedade da marca, e não attributivo della, segue-se-que, mesmo, sem registro o primeiro legitimo possuidor da marca-é o seu proprietario. Pois bem, a violação dessa propriedade origina uma obrigação ex delicto ou quasi ex $\dot{d e}$ licto, em virtude da qual o infractor póde ser accionado pelo dono da marca para indemnisal-o dos damnos que haja soffrido em consequencia da oftensa ao seu direito.

(76) Esta doutrina eminentemente racional é, aliás, confirmada pela pratica, pois coexistem, sem o minimo inconveniente, no giro commercial, marcas figurativas ou verbaes, destas sobre tudo, absolutamente eguaes, applicadas 
80.-Em sexto e ultimo lugar, emunera o art. 8 da Lei n. ${ }^{\circ}$ I 236 entre os casos de prohibição de registro os referentes ás marcas consistentes em «imitação total ou parcial de marca já registrada para producto da mesma especie, que possa induzir em erro ou confusão o comṕrador....»

A esta especie applicam-se ambas as observações ha pouco feitas em relação ao caso precedente, de reproducção de marca alheia.

Do confronto desta disposição do n. $^{\circ} 6 .^{\circ}$ com a do n. ${ }^{\circ},^{\circ}$ deste art. $8 .^{\circ}$ da Lei parece rezultar que houve desta para aquella a deslocação das palavras «total ou parcial.»

Sendo, effectivamente, mais grave em seus effeitos a reproducçãa que a imitaşão da marca, mal se comprehende a razão pela qual foi mais severo o legislador em relação a esta especie que em relação áquella.

Mais acertado e mais juridico seria dizer-se no n. ${ }^{\circ} 5^{\circ}$ «reproducção total ou parcial de marca etc.» e no n.. $6 .{ }^{\circ}$ eliminaram-se esses qualificativos, dizendo-se simplesmente «imitação de marca etc.»

81.-Ainda que equiparádas em seus effeitos juridicos, não se confundem as noções de reproducção e imitaçã $\tilde{o}$ de marcas.

A reproduç̧ão total de outra marca constitue contrafacção completa ou servil (77); a reproducção incom-

\footnotetext{
a mercadorias de especies diversas. Assim, a figura e denominação Agruia servem ao mesmo tempo para marcas de agulhas, de cimento, de tecidos, e de vinho; a figura de um leão é empregada ao mesmo tempo para marcas de papel de cigarros, de cimento e quiçá de outros productos. São tambem muito communs em industrias diversas as mesmas marcas consistentes em estrella, anjo, ancora, abelha, coraşão, flecha, etc. sob formas tigurativa, graphica ou verbal.

(77) A palavra «contrafacção», que aliás se encontra em alguns textos legaes, é perfeitamente vernacula, e não, como já ouvimos, um gallicismo. Gallicismo-porque, uma vez que ella deriva de dois vocabulos latinos? E o verbo contrafazer, 一não é portuguez castiço?!
} 
pleta, desde que comprehende elementos caracteristicos de outra marca é-contrafacção parcial.

Nos casos de imitação, parcial ou completa, pode occorrer que não haja a reproducção exacta de um só elemento da marca alheia, com tanto que no aspecto de conjuncto haja tal semelhança entre a marca authentica e a imitativa que se torne possivel entre ellas confusão, antes de confronto ou attento exame.

Ambas as hypotheses constituem, tanto na jurisprudencia patria como na estrangeira, uma só figura juridica, quer em direito civil, quer em direito penal.

82.-São estas, que ahi ficam, as restricções por expressa disposição legal, do principio generico do art. $2 .^{\circ}$ a saber que- «as marcas de industria e de commercio podem consistir em tudo... que faça differençar os objectos de outros identicos ou semelhantes de proveniencia diversa.»

Além dessas limitações, devem ser additadas, por exclusão implicita deduzida da segunda parte deste mesmo artigo (78), as seguintes:

- qualquer nome,

- denominação necessaria,

- firma ou razão social, sem fórma distinctiva

- lettras ou cifras

Estas exclusões não se estendem ás marcas já registradas em paizes estrangeiros que façam parte da União Internacional para a protecção da propriedade industrial; pois taes marcas devem ser admittidas a

(78) Esta exclusão é deduzida por um argumento a contrario sensu; pois tendo-se firmado na primeira parte do art. $2 .^{\circ}$ da Lei a regra geral sobre o que póde servir para marca, accrescenta-se neste segundo periodo:

"Qualquer nome, denominação necessaria ou vulgar, firma ou razão social e as lettras ou cifras sómente servirão para esse fim revestindo fórma distinctiva.»

Logo:-sem fórma distinctiva, os nomes, denominações, etc. não servirão para marca industrial. 
registro ou deposito $e^{m}$ protegidas no Brasil taes quaes em seu paiz de origem. (79

A mesma isenção ampara as marcas internacio naes, a saber - as depositadas no Bureau International de la Propriété Industrielle, de Berne." (80)

\section{Distincção entre marca verbal, denominação e nome commercial.}

83.-As marcas verbaes e quaesquer outras, inclusive as denominações, applicam-se a OBJECTos do commercio ou da industria; á medida que os nomes, as firmas e as razôes applican-se a sujEIros de direitos, a quem exerce commercio ou industria, individual ou collectivamente, seja pessoa natural, pessoa juridica, empreza ou estabelecimento, e por ampliação-localidade, região, ou todo um paiz.

84.-A expressão marca verbal é mais ampla que denominação, pois comprehende esta.

Consiste ella no emprego de qualquer palavra ou phrase sem o fito de dar nome ao producto, mas sómente para marcal-o, fazendo-lhe conhecida a origem pela publicidade que será dada á marca. A denominação é destinada a nomear o objecto, a differençal-o, pelo nome, dos productos congeneres de diversa procedencia. Não pode, por isso, consistir na denominação necessaria ou vulgar do objecto; pois assim o não distinguiria daquelles. Deve ser uma

(79) Convenção DE PARIs, de 20 de Março de 1883 , art. $6 .^{\circ}$ cit.

(80) LEI n. 1.236 de I904, art. $5 .^{\circ}$; DeCRETo n. 2.380 , de 20 de Novembro de 1896 , que promulgou os protocollos da Conferencia de Madrid de Abril de I891, approvados pela LEI n. 376 de 30 de Julho de 1896 . O art. $4 .^{\circ}$ do Segundo Protocollo assim dispõe: "Desde que fôr assim registrada na Repartiçâo Internacional, a protecção em cada um dos Estados contractantes será a mesma que si a marca tivesse sido ahi directamente depositada.» 
palavra original, de phantasia, podendo a originalidade ou a phantasia caracterisar-se pela applicação, e não pela novidade intrinseca da palavra.

85. - A marca consistente numa denominação pode ter por origem algum nome commmercial ou industrial (8 I). Applicada, porém, á designação de producto ou mercadoria, deixa de ser nome para ser denominação commercial ou industrial. E então é marca de commercio ou de industria, a menos, todavia que não tenha cahido no dominio publico.

86. - Ao inverso do nome commercial, a marca nominativa ou denominaçâo de phantasia, como toda e qualquer marca industrial, tem por fim distinguir um producto de outros congeneres, individualisal-o no giro commercial, tornal-o conhecido e distincto. Tudo, pois, que tiver por fim assignalar, não o productor ou o commerciante, mas o producto ou a mercadoria; não a fabrica ou a casa commercial, mas o artefacto ou a fazenda:-é marca de industria ou de commercio.

87. - A marca verbal pode ser constituida pelo nome do industrial ou commerciante, ou por um nome imaginario, de phantasia, que não seja a denominação necessaria ou vulgar do producto.

(8I) Assim aconteceu com a denominação Cognac, hoje cahida no dominio publico. Era, originariamente, apenas o nome de uma cidade da França, no departamento da Charente, e como tal, indicando a procedencia da aguardente alli fabricada, tornou-se nome commercial; passou, com o tempo, na linguagem universal a designar o proprio producto local: e assim converteu-se em denominação industrial ou mercantil, ou marca nominal.

O mesmo succedeo com as denominações, que presentemente não são marcas, porque cahiram no dominio publico: Agua da Colonia, Pontas de Paris, Folhas de Flandres, etc. e com estas, que são verdadeiras marcas nominaes e ao mesmo tempo nomes commerciaes, como tem sido firmado por varios arestos judiciaes: Chartreuse, Madeira, Vichy, Papier Duc, Café Guilherme e muitos outros. 
No primeiro caso, a marca é chamada marca nominal; no segundo, denominaşão commercial ou industrial, ou denominaşão de phantasia.

Convem não confundir a denominação commercial ou de phantasia, que é uma verdadeira marca, (pois é applicavel a productos e mercadorias), com a razão commercial, algumas vezes tambem impropriamente chamada denominaşão commercial, destinada, porem, a qualificar estabelecimento commercial. (82)

88.-Havendo, como vimos, differença por sua natureza entre marca nominal e denominação de phantasia, diversas são egualmente as condições juridicas da sua existencia e da protecção legal que as ampara.

Assim, a marca nominal constituida por um nome de commerciante ou industrial, ou de estabelecimento ou localidade, não sendo creada, portanto, por aquelle que della se apossa, carece para se tornar propriedade exclusiva delle, revestir-se de uma fórma distinctiva; pois esses nomes, se não estão no dominio commum, pertencem tambem a outros individuos, e poderiam com o mesmo direito ser usados para todos os productos da mesma localidade ou região, de qualquer procedencia industrial ou commercial que fossem.

Não é o nome de per si que constitue a marca nominal, e sim a fórma caracteristica que lhe dá feição particular.

A denominaşão de phantasia, porem, não precisa, para ser appropriada como marca, de uma fórma distinctiva. A originalidade da expressão, ou da sua applicação a objecto diverso daquelle da sua significação ordinaria, é sufficiente para lhe dar o caracter de marca.

(82) Augusto Leite, Nome Commercial, Marcas de Fabrica, n." $3^{8}$ a 48 , S. Paulo, 1903. 
Pode-se mesmo considerar essa originalidade como forma distinctiva, phonicamente apreciada.

89.--Sob o ponto de vista da protecção legal, não é, egualmente, indifferente essa distincção entre marca nominal e denominação de phantasia.

A primeira, derivada de um nome commercial, ou consistente nelle, goza das mesmas excepcionaes prerogativas. Assim, ella tem, á sombra do nome commercial, toda a amplitude da protecção da lei, independentemente de registro (83): o que não se dá com as denominações de phantazia que, não registradas, tem apenas a proteç̧ão do direito commum, e não a da legislação iudustrial.

90. - Não são uniformes as legislações dos povos cultos no tocante a esta especie de marcas verbaes. Nalguns paizes a lei não reconhece a propriedade industrial das denominações arbitrarias, inventadas para designarem um producto. Entre estes menciona as seguintes Luiz Donzei (84): Belgica, Brazil, Portugal, Suissa, Rumania. Victoria, Turquia, Cabo da Bôa Esperança, Inglaterra, Republica Argentina, França, Canadá e Uruguay. Ao contrario, não reconhecem esta especie de propriedade industrial: a Hespanha, a Italia a Hollanda, a Austria-Hungria e a Russia.

91.--Que a denominação de phantasia é marca e não nome, corroboram a demonstração que havemos

(83) "Convenção DE Paris de 20 de Março de i883, art. 7:

«O nome commercial será protegido em todos os paizes da União, sem obrigação de deposito, quer faça ou não parte de uma marca de fabrica ou de commercio". pag. 92.

LEI N..$^{\circ}$ I 236 de I904, art. 13 n. 9.

(84) L. Donzel, Commentaire de la Convention de P'aris, etc. 
feito os mais notaveis autores, que se tem occupado destes assumptos.

Henrigue Allart, sem a definir, nos dá a respeito della a seguinte elegante noção:

"Il arrive qu'un industriel, pour faire connaître au public ses produits, leur donne un nom spécial qui les personefie en quelque sorte, comme le nom patronymique personnifie l'individu. Frappant l'oreille au même temps que la wue, le nom récommende et impose le produit à l'attention du consommateur; il donne, par là même, au fabricant la plus sérieuse des gavanties. Ce NOM, cette DÉNOMINATION, constitue une MARQUE DE FABRIQUE protegée par la loi...»

(85) Mencionaremos apenas ns seguintes:

ARMengand AInÉ, obr. cit, pig. 9: "La dénomination ne doit pas êlre confondue avec le nom. . . Elle est toujours une désignation du produit lui-même el peut constituer une marque de fabrique, pourvu qu'elle soit toujours nouvelle et que d'ailleurs elle ne soit pas nécessaire, c'est à dire, indispensable pour désigner le produit au quel elle s'applique».

GEORGES BRY, Cours de Législation industrielle, pag. 456: "En dehors des noms des fabricants ou du lieu de fabrication, qui sont protégés comme noms par la loi de 1824 , ou, dans leurs formes distinctives, comme marques nominales, por la loi de 1857; il peul y avoir d'autres noms, em. ployés pour désigner un produit et qui peuvent alors, seulement à titre de marques de fabrique ou de commerce, constituer une propriété privative. Ce sont les noms imaginaires, servant d'etiquette, comme par exemple le CHAMpagne Marquis de Lorne, l'Eau d'Athìnes, de Palmyre, la BenedicTINE, la BoUgIE DE L'ETOILE; dans ce cas c'est la denomination méme indépendemment de tout autre forme qui constitue la marque. Ce sont des noms patronymiques appartenants à des tiers et dont l'emploi est autorisé, comme marque de prodnit; par ex.: les "ALLUMETTES WILSON», la «POUDRE DE RIZ SARAh BERnARDT». Toutes les dénominations de fantaisie et purement arbitraires, qui ne resultent nullement de la nature du produit, peuvent constituer des marques de fabrique».

C. Counin, obr. cit. vol. III pag. II4 e seguintes, estuda ex professo as denominaf̧oes, e assim começa: " $A$ la difference des "noms» qui ne peuvent constituer des marques qu'autant qu'ils affectent un aspect extérieur spécial, les DÉNOMINATIONS sont susceptibles, en elles mèmes et par elles mèmes, indépendemment de toute FORME DISTINCTIVE, de faire l'object d'une proprieté exclusive à titre de marque».

Vejam-se ainda, na conformidade da mesma doutrina, Pouillet, obr. cit. ns. 46 e 460 ; A. Braun, obr. cit. ns. 39 e seguintes; Dufourmantelle, obr. cit., pag. 68; H. Allart, obr. cit. ns. I 19 e seguintes; Gianini, Concorrenza sleale, ns. 44 e seguintes. 
92. - Cumpre agora dizermos ainda algumas palavras sobre o nome commercial.

$\mathrm{O}$ nome commercial que Calmels considerava como «o toque de reunir» da freguezia do commerciante, o «thermometro do seu credito», e que Pouillet denomina «a bandeira da mercadoria»: serve para individualisar o sujeito do commercio ou da industria, como o nome civil se identifica com o individuo do qual elle resume a personalidade. (86)

Não é licito, por conseguinte, confundir-se esta especie juridica com as marcas verbaes consistentes em nomes, originariamente de pessoa commerciante ou industrial, de estabelecimento ou de localidade, mas subsequentemente applicados a designarem productos ou mercadorias, e constituindo assim-marcas nominativas; nem, tão pouco, com as denominações de phantasia, egualmente destinadas á mesma applicação.

Esta doutrina é corroborada com as licções de todos os jurisconsultos que tem escripto sobre a natureza do nome commercial e industrial (87)

93.-Recapitulando, reproduziremos aqui as seguintes conclusões de um trabalho a que nos temos referido e no qual tambem colloboramos: (88)

$\mathrm{O}$ nome commercial pode ser considerado sob dois pontos de vista - restricto e amplo.

No primeiro caso, elle é a firma do commerciante, a razã 0 commercial de uma sociedade ou associação.

(86) AUgusto LeITE, obr. cit. n. 20.

(87) Consultem-se, entre outros, M. Pelletrer, obr. cit. verb. «Nom commercial ou industriel"; BOZERIAN, Journal Officiel, sess. de 1879, Senat, Annexes n. 185; RenÉ Parbier, De la Concurrence déloyale, pag. 70; JAMES VALloTON, obr. cit., $\S 39$.

(88) AUgusto Leite, obr. cit. ns. 2 I a 27. 
No segundo caso, o nome commercial é extensivo ao estabelecimento commercial, ou ao lugar onde este é situado.

Assim, pois, são nomes commerciaes;

a) o nome individual do commerciante;

b) a rasão social da pessoa juridica;

c) o nome do estabelecimento commercial, e

d) o nome do lugar, da situação do mesmo.

94. - «Nos primeiros casos, ( $a$ e $b$ ) o nome commercial tem a protecção da lei, em qualquer parte em que ella se torne necessaria.

O seu uso pode ser interdicto pelo portador ou pelo dono do nome a qualquer pessoa, sem excepção.

Nos dois outros casos, (c e d) duas hypotheses se verificam:

I. $^{a}$ O nome commercial é o do estabelecimento: o seu uso é exclusivo, e garantido dentro dos limites territoriaes de uma cidade ou de um paiz. (89)

2. ${ }^{a} \quad$ O nome é o de uma localidade: o seu uso pertence, em commum, a todos os habitantes da localidade; estes podem impedir o uso delle por outros que não residam na mesma circumscripção territorial.

Ha casos, porém, em que a protecção ao nome de proveniencia é tão ampla como a do nome commercial, em sentido restricto: a saber-quando aquelle

(89) Por exemplo: o nome commercial Notre Dame, de um estabelecimento commercial do Rio de Janeiro: os nomes Louvre, Bon Marché, Primptemps, La Samaritaine, etc. de grandes armazens universaes de Paris,' tem homonymos em quasi todas as grandeś cidades do mundo; e isto sem inconveniente algum. Assim tambem os nomes Grand Hotel, Hotel d'Europe, Flotec Central, Restaurant de Paris, Café de Londres, Casa Havaneza, Loja da China, Leão de Ouro, Banco do Commercio, Emporio Normal, etc. Localisados em cidades diversas esses estabelecimentos, a homonymia os não prejudica : não ha, pois, razão, para que ella seja vedada em absoluto. 
nome é o de uma propriedade de dominio privado. (90)

\section{Divisão e classificação das marcas.}

95.-A classificação mais geral das marcas é aquella que as distingue em-marcas de industria e marcas de commercio.

Esta divisão, porém, além de não ser irreprehensivel, mesmo em theoria, nenhum alcance tem na pratica. $\mathrm{Na}$ verdade, todos os preceitos juridicos applicaveis a uma especie o são egualmente á outra.

E' esta a razão pela qual, não sómente nos trabalhos didacticos, mas tambem em textos legaesdeixa muitas vezes de ser feita essa discriminação technica. E são assim empregadas, ora as expressões genericas marcas industriaes, como designativas de todas as marcas, inclusive das de commercio: ora, a designação marcas de fabrica, no mesmo sentido genericn; ora finalmente, por opposição uma á outra, as fórmulas - marcas de industria e de commercio, assumindo, então, cada uma-significação restricta e exclusiva.

96. -- Em razão da finaliciade essencial da marca, que é differençar os objectos, assignalando-lhes a origem industrial ou a procedencia'mercantil, - a melhor marca seria a propria assignatura do productor ou do commerciante ou a inscripção do seu nome sobre o

(90) Pourller, obr. cit. n. 409: Le nom d'un domaine privé appartient, bien entendu, au proprietaire de ce domaine, et n'appartient qu'à lui. La propriété du nom suit la propriété du domaine, et nul autre, à moins d'autorisation, ne peut en user.» 
producto ou a mercadoria. (9I) $\mathrm{E}$ de facto, em fundo, a marca é como a assignatura.- - La marque, diz a exposição de motivos da lei belga, la marque ne diffère de la signature du fabricant que par la forme; elle n'est autre chose que cette signature, modifiée d'après les exigences du commerce et d'après la nature des objets fabriqués.» (92)

Como, porém, por diversas razões, nem sempre seria possivel, commodo ou conveniente a applicação do proprio nome, assignatura ou razão social do commerciante ou industrial, o legislador com sobejo criterio permittio para o mesmo fim a collocação de outro signal ou qualquer outro meio de marcar os objectos. Cada um desses meios constitue uma das muitas modalidades das marcas.

97. - Consideradas sob o ponto de vista dos seus caracteres accidentaes, dividem-se as marcas em:

a) verbaes,

b) figurativas,

c) formaes $\mathrm{e}$

d) mixtas.

Destinam-se as da primeira cathegoria a impressionar a outiva; as da segunda e terceira, a vista; as da quarta, a ambos os sentidos, e até ao tacto.

A significação clara e precisa de cada uma das expressões que qualificam estas tres especies enumera-

(9I) Ph. Dunant, obr. cit. n. 33: "La marque la plus naturelle est le nom ou la signature, et c'est pourquoi la loi (refere-se o autor á lei federal suissa de 1890 ) nomme en premier lieu les raisons de commerce.

Mais le nom, la signature ou la raison de commerce ne peuvent pas toujours étre reproduits tout au long sur les objets de petite dimension; en outre, ils ne frappent pas l'ail, ils n'attirent pas l'attention, et par consequent se gravent mal áans la mémoire; de là l'usage, si ancien dejà, ...de remplacer le nom ou la signature par un signe, un symbole, choisi arbitrairement selon la nature du prodult et les goûts de la clientelle.»

(92) A lei belga de Abril de 1879. 
das dispensa sobre cada uma dellas qualquer noção explicativa.

98.-As marcas verbaes, subdividem-se em:

a) marcas nominaes,

b) denominações necessarias ou vulgares,

c) denominações de phantasia, e

d) marcas verbaes restricto sensu, consistentes em palavras originaes, disticos, proverbios, etc.

As duas primeiras teem que se revestir de forma distinctiva (93); as outras independem desta condição.

99.-As marcas figurativas, de multiplas e variadissimas modalidades, podem ser subdivididas nas seguintes especies:

a) emblematicas

b) consistentes em vinhetas, ou

c) em lettras,

d) algarismos,

e) figuras geometricas $\mathrm{e}$

f) n'outros signaes, ou finalmente

g) complexas.

As marcas consistentes em lettras e algarismos devem ter forma distinctiva. (94) Quanto ás demais marcas figurativas, basta que não reproduzam ou não imitem outra marca já registrada e, naturalmente, tenham o requisito essencial de toda marca, a saber,sirvam para differençar os productos ou mercadorias.

As marcas figurativas complexas são as que se compõem de dois ou mais dos elementos enumerados.

(93) LEI cit. n. I 236 de I 904, art. $2 .^{\circ}$, segunda parte.

(94) LEI cit. n. 1236 de 1904 , art. $2 .^{\circ}$, segunda parte. 
100. - As marcas formaes recebem essa designação, porque consistem na fórma dada:

a) directamente aos productos, ou

b) aos respectivos involucros e recipientes, e

c) aos appendices e accessorios destes.

Faz-se necessario, evidentemente, que essa fórma não seja a commum ou habitual do objecto, aliás o não distinguiria dos congeneres; mollograr-se-ia, assim, o fim essencial da marca.

Podem, egualmente, ser incluidas entre as marcas formaes as consistentes em signaes applicados em relevo ou em sulco ou depressões nos proprios objectos ou nos seus envolucros ou recipientes.

101. - Vejamos agora o que seja marca mixta ou complexa, em sentido geral.

Consta ella de um conjuncto de elementos diversos, podendo comprehender-nome commercial ou industrial, denominação vulgar, denominação de phantasia, e ainda-emblemas, vinhetas, disticos, lettras, algarismos, molduras, tarjas, etc.

E' esta a especie mais geralmente adoptada na pratica. (95)

Participando, pela sua natureza, dos caracteres de cada uma das outras especies já mencionadas, as

(95) A. BraUn, obr. cit. n. 32: «Il est rare qu'en faisant choix d'une marque, un industriel ou un commergant se borne a adopter soit un embleme, soit une vignette, soit un symbole quelconque. La plupart du temps, la marque consiste dans une etiquette portant à la fois, dans une cartouche ou un encadrement spéciâl, lâ denomination donnée au produ't, le signe conventionnel et le nom du producteur ou du dêbitant. La marque s'entend âlors de l'ensemble de ces signes. Parfois encore, cette marque comprend, par surcroit, des empreintes placées sur une ou plusieurs autres faces du produit et sur son enveloppe.» 
marcas mixtas ou complexas, são reguladas, conforme os casos, pelas mesmas normas juridicas das outras.

102.-Poderiam ainda ser divididas as marcas, em razão do modo da sua applicação; pois sobre os productos e mercadorias ou os respectivos involucros, recipientes ou seus accessorios, ellas são appostas ou applicadas:

a) mediante rotulos impressos, lithographados, gravados etc.

b) sellos, estampilhas, medalhas, capsulas etc.

c) sinetes, carimbos sigillos, etc.

d) em relevo, depressão, incrustação, conformação etc.

e) por gravação, bordadura, textura, douração, estampação, a esmeril, a fogo, a alcool etc.

Esta, porém, e outras classificações, que poderiam aqui ficar delineadas, não tem senão valor meramente theorico e doutrinario.

Deixam, por isso, de ser interessantes.

S. Paulo, Março- 1905.

Almeida Nogueira. 